Ks. Mariusz Sztaba

Towarzystwo Naukowe KUL

\title{
REALIZM DOŚWIADCZENIA ETYCZNEGO U PODSTAW ADEKWATNYCH KONCEPCJI WYCHOWANIA MORALNEGO. REFLEKSJA W ŚWIETLE PERSONALIZMU ETYCZNEGO KAROLA WOJTYEY I JEGO UCZNIÓW
}

The realism of ethical experience on the grounds of the appropriate concept of moral education. A reflection in light of the ethical personalism of Karol Wojtyla and his students

Su m mary: Moral education, as an inner form of every other field of education, is essential in the lifelong process of education. The essence of the concept of moral education depends upon the philosophical tradition in which it has been shaped - in realism or in idealism. Moral education, being under the influence of idealism, loses contact with the real student and becomes inadequate or even utopian (e.g. Rousseau's moral education, socialist education, and postmodernist education). In turn, moral education shaped on the ground of realism aims to truly recognize the student and to adequately shape his/her morality. The article presents the connection between the realistic concept of moral education and specific normative ethics built on the basis of realistic ethical experience as presented by the Lublin School.

Keyw ord s: ethical experience, ethical personalism, cognition, truth, moral good, conscience

\section{Wstęp}

Wychowanie moralne jest „wewnętrzną formą” i wspólnym mianownikiem każdej działalności wychowawczej, ponieważ oznacza przede wszystkim pomoc w rozwoju moralnym osoby zarówno w sferze poznawczej (w uświadomieniu sobie tego, co jest dobre, a co złe - prawda o dobru); w sferze emocjonalnej (w rozwijaniu wrażliwości moralnej) oraz w sferze behawioralnej (w konkretnym postępowaniu moralnym)1.

\footnotetext{
${ }^{1}$ Zob. Mieczysław Łobocki, Wychowanie moralne w zarysie (Kraków: Wydawnictwo „Impuls” 2002), 1117; Krzysztof Maliszewski, Teoria wychowania moralnego w pedagogice kultury II Rzeczypospolitej (Katowice: Wydawnictwo UŚ 2004), 102-104; Zbigniew Marek, Podstawy wychowania moralnego (Kraków: WAM 2005), 11-12, 60-64; Ryszard Adrjanek, Wychowanie moralne w nauczaniu Jana Pawta II (Kraków: Wydawnictwo WSF-P „Ignatianum” 2003).
} 
W wychowaniu moralnym chodzi o uświadomienie i pielęgnowanie w osobie zdrowej ambicji bycia człowiekiem poprzez zmierzanie do integralnego rozwoju osobowości nadającego pełne znaczenie życiu człowieka ${ }^{2}$.

Ponieważ wychowanie moralne jest kluczowe w działalności wychowawczej i bezdyskusyjnie potrzebne w czasach wszechpanującej ekonomii liberalnej, której zasady (między innymi rywalizacja i maksymalizacja zysku - tak zwana „logika rynku”) przenoszone są na relacje międzyludzkie, dlatego pedagodzy odpowiedzialni za integralny rozwój młodych pokoleń powinni wielką troskę i uwagę poświęcić tej właśnie dziedzinie wychowania3. Realizacja tego postulatu nie jest jednak prosta ani w teoretycznym namyśle, ani w praktycznym działaniu. Istota, cele i przebieg wychowania moralnego zależą od wielu czynników. Różny ich dobór decyduje o ostatecznym kształcie konkretnej koncepcji bądź teorii wychowania moralnego. U podstaw tej różnorodności znajdują się dwie wielkie tradycje filozoficzne: realizm i idealizm, które konkurują ze sobą, mając odmienny wpływ na ontologię, epistemologię, metodologię, antropologię i aksjologię danej koncepcji wychowania, pedagogii, czy wreszcie pedagogiki. One też w gruncie rzeczy decydują o istocie konkretnej etyki, która odnosi się do moralności (wychowania moralnego) podobnie jak teoria do praktyki4. Już na tym etapie refleksji można dostrzec istotną kwestię dotyczącą tego, co decyduje o adekwatności danej etyki, rozumienia moralności i w końcu wychowania moralnego. Można to zagadnienie uszczegółowić, pytając, jakiej etyki potrzebuje współczesny człowiek, aby pomagała mu urzeczywistniać moralną praktykę.

Proponowany artykuł jest próbą wskazania na realistyczne i integralne doświadczenie etyczne jako fundament i punkt wyjścia w odczytywaniu fenomenu moralności oraz proces tworzenia adekwatnej etyki i koncepcji wychowania moralnego. $\mathrm{W}$ celu realizacji tego zamierzenia na początku zostaną przywołane wybrane koncepcje wychowania moralnego w świetle sporu pomiędzy realizmem a idealizmem. W dalszej części zostanie zaprezentowana istota sporu o moralność i etykę; dotychczas zaprezentowane treści stanowią istotny kontekst dla dalszych refleksji dotyczących realistycznego i integralnego doświadczenia etycznego,

\footnotetext{
${ }^{2}$ Wychowanie moralne jest procesem całożyciowym (w pewnym momencie rozwoju osoby przechodzi $\mathrm{w}$ samowychowanie, autoformację moralną) służącym „kształtowaniu człowieka $\mathrm{i}$ to nie w sensie jego rozwoju jako gatunku, lecz w znaczeniu doskonalenia każdej indywidualnej jednostki we wszystkich dziedzinach życia i działalności. W tym też znaczeniu należy mówić o wychowaniu moralnym rozumianym jako kształtowanie całej osoby"(Marek, Podstawy, 62-63).

3 Zob. Jarosław Horowski, Wychowanie moralne wedhug pedagogiki neotomistycznej (Torun: Wydawnictwo Naukowe UMK 2015), 13-14.

${ }^{4}$ Bardzo interesujące są sprzęgnięte relacje pomiędzy etyką i moralnością, o czym dość często zapominają pedagodzy, tworząc konkretną koncepcję wychowania moralnego. Do etyki dochodzimy przez moralność, tzn. przedrefleksyjna praxis moralna poprzedza etykę jako twór racjonalny, prowadząc także do poszukiwania wartości absolutnej dostarczającej racji wyjaśniającej dla przeświadczeń moralnych. Z kolei człowiek, aby uniknąć błędów moralnych m.in. poprzez poddanie fenomenu sumienia i jego treści dialogowi z innymi sumieniami, powinien czynić to za pośrednictwem adekwatnej etyki (zob. Ryszard Wiśniewski, „Wartość absolutna a problemy moralnej praxis", w: Etyka. Filozoficzna etyka życia spetnionego, część II, red. Stanisław Janeczek, Anna Starościc [Lublin: Wydawnictwo KUL 2016], 600-612).
} 
poddawanego gruntownej analizie przez Lubelską Szkołę Personalizmu Etycznego5. Całość artykułu zostanie domknięta podsumowaniem i postulatem natury pedagogicznej.

Dla jasnego zrozumienia problemu zapowiedzianego w tytule artykułu, należy jeszcze raz podkreślić, że główny akcent tych rozważań dotyczy ukazania specyfiki i elementów strukturalnych doświadczenia etycznego, które dzięki swojemu realizmowi i integralności jest/może być fundamentem dla adekwatnego wychowania moralnego. Istotą omawianych zagadnień jest więc nie prezentacja jakiejś koncepcji wychowania moralnego, ale opis elementów strukturalnych realistycznego doświadczenia etycznego; artykuł jest więc początkiem swoistej drogi poszukiwania i tworzenia koncepcji adekwatnego wychowania moralnego, odpowiadającego wyzwaniom współczesnych czasów hic et nunc.

\section{Wychowanie moralne w kontekście sporu pomiędzy realizmem a idealizmem}

Tym, co stanowi kryterium wyodrębnienia dwóch wspomnianych wielkich tradycji w filozofii (realizmu i idealizmu) oraz tworzonych wich nurcie systemów filozoficznych, a także pedagogicznych (wraz z konkretnymi koncepcjami wychowania) jest ontologia (dokładniej - metafizyka) ${ }^{6}$ i epistemologia, które w dalszej kolejności rzutują na rozumienie antropologii, aksjologii oraz metodologii7.

Idealizm (łac. idealis: związany $\mathrm{z}$ ideą) to stanowisko, zgodnie z którym przedmiotem filozofii i tworzywem jej myślenia systemowego są idee. Idealizm jest nurtem wewnętrznie zróżnicowanym, bowiem wyrasta z pnia tak zwanej filozofii

\footnotetext{
${ }^{5}$ Szkołę tę stworzył Karol Wojtyła wraz ze swoimi bezpośrednimi uczniami: ks. Tadeuszem Styczniem i ks. Andrzejem Szostkiem, a dzisiaj rozwijają jej myśl ich uczniowie, m.in.: Kazimierz Krajewski, do którego najczęściej odwołuję się w swoich refleksjach z trzech powodów. Po pierwsze, dokonuje on systematycznej analizy i syntezy myśli wspomnianych etyków. Po drugie, w sposób twórczy rozwija ich rozważania, zachęcając tym samym innych autorów działających w orbicie refleksji tej szkoły do współmyślenia. Po trzecie, odwołując się w większości do tego autora, nie mnożę przypisów i bibliografii, aby sprawiać wrażenie erudycji, ufając tym samym, że zainteresowany czytelnik, docierając do publikacji tego autora, za jego pośrednictwem dotrze także do źródłowej literatury. Przywoływana szkoła wyrosła z twórczego i krytycznego dialogu z innymi wielkimi koncepcjami filozoficzno-etycznymi (zob. Kazimierz Krajewski, „Personalizm etyczny w lubelskiej szkole filozoficznej”, w: Etyka. Koncepcje etyki, część I, red. Stanisław Janeczek, Anna Starościc [Lublin: Wydawnictwo KUL 2016], 229-261; Tadeusz Styczeń, „Kardynał Wojtyła - filozof moralista”, w: Etyka. Koncepcje, 381-393).

${ }^{6}$ Wbrew obiegowym opiniom ontologia nie jest synonimem metafizyki. Ta pierwsza, powstała w XVII wieku, dotyczy bytów możliwych i zajmuje się samym pojęciem bytu. Natomiast metafizyka, powstała w starożytności, dotyczy bytów realnych, a więc rzeczywistości. Metafizyka to obrona poznania dorzecznego, otwartego na poznanie racjonalne, które próbuje ogarnąć całą rzeczywistość (zob. Piotr Jaroszyński, Metafizyka czy ontologia? [Lublin: Polskie Towarzystwo Tomasza z Akwinu 2011]).

${ }^{7}$ Dla potrzeb realizacji tematyki artykułu zostaną obecnie zaprezentowane istotne elementy idealizmu i realizmu (ontologia i epistemologia), z równoczesnym wskazaniem na wybrane koncepcje wychowania moralnego, osadzone w jednej bądź drugiej tradycji. Bardziej szczegółowo zagadnienie to umówione zostało w artykule: Mariusz Sztaba, „Rzecz o fundamentalnym wyborze pomiędzy realizmem a idealizmem w tworzeniu adekwatnej koncepcji wychowania”. Roczniki Pedagogiczne, 1 (2015): 27-46.
} 
krytycznej rozpiętej pomiędzy dwoma przeciwstawnymi nurtami: racjonalizmem (empiryzm, nominalizm, konceptualizm, konwencjonalizm, relatywizm) a irracjonalizmem (intuicjonizm, woluntaryzm, emotywizm, fideizm, natywizm, common sense itd.) ${ }^{8}$. Pierwszy nurt bardzo wyraźnie urzeczywistniał się w tak zwanym modernizmie, którego prekursorami byli Platon, J.G. Fichte, G.F.W. Hegel, A. Comte i K. Marks. Drugi zaś nurt „wcielił się” w obecny dziś postmodernizm, którego prekursorami byli J.J. Rousseau, F. Nietzsche, J. Lock oraz I. Kant9.

Według idealistycznej ontologii tym, co naprawdę istnieje, są idee poznawcze będące danymi pierwotnymi, otaczający zaś świat to dane pozorne. Takie rozumienie ontologii ma bezpośredni przekład na epistemologię: idealiści podważają nie tylko rezultaty poznania spontanicznego, odmawiając rozumowi udziału w doświadczeniu źródłowym oraz przypisując jego działalności względność i umowność, ale także istnienie świata suponowanego przez poznanie zmysłowo-intelektualne. W idealizmie ważniejsze od poznania jest myślenie (często wymyślanie), czyli różne rozumowe operacje dokonywane na uprzednio już ujętych obrazach, znakach rzeczy, będących reprezentacją wyobraźniową i pojęciową, co pociąga za sobą pełną subiektywizację wyjaśnień i interpretacji filozoficznych oraz pedagogicznych ${ }^{10}$. Idealizm, nie ufając naturalnemu doświadczeniu i poznaniu zmysłowo-intelektualnemu, odrywa je od realnego świata, zamieniając poznanie na myślenie będące czynnością niepoznawczą, operujące ideami i konstruujące $\mathrm{z}$ nich rozmaite wizje człowieka, świata oraz społeczności ${ }^{11}$. W idealizmie pojmowanie świata dokonuje się na drodze spekulacji, czyli metody dedukcyjnej. Wysiłek poznawczy nie jest skierowany na analizę rzeczywistości, tylko na analizę pojęć oraz sposobów ich wytwarzania. W takich analizach człowiek kreuje rzeczywistość w wykreowanych ideach-pojęciach ${ }^{12}$. Wiedza

\footnotetext{
${ }^{8}$ Przyczyny idealizmu, jego istotę, historyczne przejawy i odmiany, a także jego ontologię i konsekwencje kulturowe omawia Henryk Kiereś w artykule: „Idealizm”, w: Powszechna encyklopedia filozofii, t. 4, red. Andrzej Maryniarczyk i inni (Lublin: Polskie Towarzystwo Tomasza z Akwinu 2003), 721-726.

${ }^{9}$ Zob. tamże, 725 .

${ }^{10}$ Zamiana poznania na myślenie to pomylenie dziedzin aktywności człowieka. Już Arystoteles dokonał rozróżnienia racjonalnej ludzkiej aktywności na: teorię - praxis - poiesis. Celem poznanie teoretycznego jest odkrycie faktycznej struktury rzeczywistości i odpowiada mu prawda. Celem zaś poznania praktycznego jest realizacja rozpoznanego i uznanego dobra. $Z$ kolei celem poznania poietycznego (wytwórczego) jest piękno. Ten ostatni rodzaj poznania związany jest z szeroko rozumianą dziedziną wytwórczości człowieka, tak w sensie artystycznej wizji, jak i jej wykonania - techne. Tą formą poznania rządzi tzw. licentia poetica (zob. Marian Nowak, Teorie i koncepcje wychowania [Warszawa: Wydawnictwo Akademickie i Profesjonalne 2008], 39-43).

${ }^{11}$ W związku z powyższymi uwagami napisze Mieczysław A. Krąpiec, że ,jeśli poznanie nie wychodzi od spontanicznie dostrzeganej rzeczywistości, lecz od refleksji nad własnym poznaniem, wówczas tworzy ideologie (polityczne, społeczne, gospodarcze) i mity. Czym innym jest realne poznanie, a czym, innym myślenie. Poznanie dotyczy rzeczy realnych, natomiast myślenie jest operacją rozumu na uzyskanych w poznaniu pojęciach i sądach" (Mieczysław A. Krąpiec, „Realizm poznawczy”, w: Powszechna encyklopedia, 668).

12 Dzisiaj pod wpływem idealizmu nadużywa się pojęcia „kreowanie”, które jest ulubionym terminem różnorakich ideologii. To F. Nietzsche, dokonując przewartościowania wszystkich wartości, na ich miejsce wprowadził pluralizm i relatywizm oraz kreatywność. Był on także autorem modelu człowieka jako istoty stwarzającej wartości, a nie odkrywającej dobro. Jego zdaniem prawdziwe wartości to te, które mają moc kreowania wielkich systemów myślowych - politycznych, filozoficznych i religijnych (zob. Imelda Chodna,
} 
o człowieku i świecie przybiera charakter aprioryczny. Zaniechanie poznania (kontaktu z rzeczywistością) na rzecz myślenia skutkuje w zakresie epistemologii i metodologii między innymi następującymi kluczowymi błędami idealizmu: a) rozbiciem genetycznej jedności zmysłów i rozumu wich funkcjach poznawczych; b) przypisywaniem funkcji poznawczych czynnościom i przeżyciom niepoznawczym (emocjom, językowi itd.); c) operowaniem pozaracjonalnymi kryteriami oceny poznawania $^{13}$.

Koncepcje wychowania moralnego tworzone wnurcie tradycji idealizmu oderwane są od rzeczywistości (realnego wychowanka, wychowawcy isytuacji wychowawczej) na rzecz dowolnie kreowanej wizji człowieka i moralności, zarówno w wymiarze osobowym, jak i społecznym. Przykładem idealistycznej koncepcji wychowania moralnego w wersji racjonalistycznej było chociażby socjalistyczne wychowanie moralne, które wykreowało nowego socjalistycznego człowieka, nowe (utopijne) socjalistyczne społeczeństwo oraz socjalistyczną moralność (kodeks moralny budowniczego komunizmu) w myśl założeń światopoglądowych marksizmu-leninizmu, u podstaw których znajdował się materializm dialektyczny i historyczny ${ }^{14}$.

Idealistycznym wychowaniem moralnym w wersji irracjonalnej jest propozycja naturalnego wychowania J.J. Rousseau, który wykreował człowieka dobrego z natury, przypisując wymyślonej (a nie rozpoznanej) przez siebie naturze zdolność do spontanicznego rozwoju ku dobru. Zdaniem przywołanego autora, wychowanie moralne powinno dokonywać się dopiero pomiędzy 16 a 20 rokiem życia, kiedy to następuje przekształcenie rzekomo już rozumnej istoty w kochającego i czującego człowieka. Rousseau wyobrażał sobie, że człowiek chowany przez 15 lat w samotności, z dala od bliźnich i rodziny, z próżnią w sercu, może nauczyć się uczuć szlachetnych na zawołanie. Dotychczas dziecko ustosunkowywało się obiektywnie do ludzi i rzeczy, teraz natomiast zaczyna to robić bardziej subiektywnie, pragnąc miłości i przyjaźni osób, które się o nie troszczą i darzą życzliwością. Dlatego wychowanie moralne miało w tym okresie uczyć młodego człowieka czystej miłości oraz uświadamiać mu wartość szczerej przyjaźni będącej pierwszym uczuciem, do którego jest skłonny młody, właściwie wychowany człowiek ${ }^{15}$.

Innym przykładem idealistycznego wychowania moralnego w wersji irracjonalnej są propozycje powstałe w ramach szeroko rozumianej pedagogiki postmodernistycznej. Twórca i niestrudzony propagator postmodernistycznej

Edukacja amerykańska. Drogi i bezdroża [Lublin: Wydawnictwo KUL 2008], 148-162). J. Ratzinger zauważa, że termin ten zaistniał w oderwaniu od Boga, który jest sensu stricto Creator ex nihilo - na gruncie światopoglądu marksistowskiego i związany był z przekonaniem, że „w świecie, który sam w sobie jest bezsensowny i powstał w wyniku ślepej ewolucji, człowiek w sposób twórczy buduje sobie nowy lepszy świat (Joseph Ratzinger, Duch liturgï, przeł. Eliza Pieciul [Poznań: Klub Książki Katolickiej 2002], 151).

${ }^{13}$ Zob. Kiereś, „Idealizm, 725.

${ }^{14}$ Zob. Heliodor Muszyński, Podstawy wychowania spoleczno-moralnego (Warszawa: PZWS 1967).

${ }^{15}$ Zob. Andrzej Gielarowski, „Natura, jako to, co upragnione. Analiza koncepcji natury ludzkiej u J.J. Rousseau", w: Oblicza natury ludzkiej. Studia i rozprawy, red. Piotr Duchliński, Grzegorz Hołub (Kraków: Wydawnictwo WAM 2010), 53-78. 
moralności - Zygmunt Bauman - „walcząc” z niepopularnymi dzisiaj kodeksami etycznymi, postuluje prywatyzację moralności, absolutyzację wolności oraz przywrócenie uczuciom odpowiedniego statusu w dziedzinie życia społecznego ${ }^{16}$. Bardzo inspirujące, ale także zatrważające w swojej wymowie, byłoby prześledzenie współczesnych koncepcji wychowania moralnego pozostających w zasięgu odziaływania pedagogiki postmodernistycznej, która z zasady zajmuje się kreowaniem świata osób, ich natury, płci (gender), relacji, uczuć, wartości, języka (nowomowy) i innych ${ }^{17}$.

Realizm (łac. realis: rzeczywisty, faktyczny, odnoszący się do rzeczy) jest przeciwieństwem idealizmu; to nurt także zróżnicowany, na co wskazuje historia i występujące w niej różne odmiany i rodzaje realizmu: skrajny (naiwny, bezkrytyczny) ${ }^{18}$, umiarkowany, psychologiczny, socjologiczny, prawniczy, moralny itd. ${ }^{19}$ Zwracając uwagę na realizm epistemologiczny (natura poznania) i metafizyczny (natura istnienia), dostrzega się, że podstawową tezę metafizyczną tej tradycji stanowi założenie, iż świat zewnętrzny jest dany w doświadczeniu oraz istnieje realnie, niezależnie od aktów poznawczych i procesów zachodzących w umyśle poznającego podmiotu i jego wytworów (konstruktów) ${ }^{20}$. Z realizmem metafizycznym ściśle powiązany jest realizm epistemologiczny, czyli ufundowany na założeniu, że istnieje prawda obiektywna, a rzeczywistość jest poznawalna, przy czym stojąc na gruncie realizmu krytycznego, zwraca się uwagę na pewne problemy związane z procesem poznawania, które powodują deformacje poznawcze. W realizmie epistemologicznym podkreśla się zgodność ludzkiego poznania z rzeczywistością. Ludzki rozum (recta ratio), posiadając w sobie immanentną zdolność pozwalającą mu dotrzeć do prawdy i uchwycić ją, może odkryć prawdę ontyczną (prawdę samego bytu) ${ }^{21}$. W realistycznym poznaniu najważniejszy jest kontakt z rzeczywistością wyrażony poprzez stwierdzenie istnienia poznawanej rzeczy. Spontaniczne poznanie jest więc nakierowane na istniejące byty, a nie na pojęcia i idee, które poznajemy w aktach refleksji ${ }^{22}$.

Przykładem realistycznego wychowania moralnego są jego koncepcje tworzone w ramach pedagogiki neotomistycznej. Posiadają one jednak ograniczenia

\footnotetext{
${ }^{16}$ Zob. Zygmunt Bauman, Etyka ponowoczesna, (Warszawa: Wydawnictwo Aletheia 2011).

${ }^{17}$ Zob. Andrzej Bronk, Zrozumieć świat wspótczesny (Lublin: TN KUL 1998), 23-74; Stanisław Kowalczyk, Idee filozoficzne postmodernizmu (Radom: Wydawnictwo Polwen 2004).

${ }^{18}$ Naiwny realizm uznaje treści spostrzeżeń za wierne odbicie ukazującego się świata, co sprawia, że są one dostępne dla wszystkich w ten sam sposób i istnieją tak, jak je spostrzegamy.

${ }^{19}$ Zob. Jarosław Gara, „Realizm”, w: Encyklopedia pedagogiczna XXI wieku, t. V, red. Tadeusz Pilch (Warszawa: WA „Żak” 2006), 64-66.

${ }^{20}$ Zob. tamże, 67.

${ }^{21}$ Zob. Edmund Morawiec, „Umysł ludzki w koncepcji klasycznej nurtu realistycznego”, w: Rozum otwarty na wiarę, red. Andrzej Maryniarczyk, Arkadiusz Gudaniec (Lublin: Polskie Towarzystwo Tomasza z Akwinu 2000), 55-66.

${ }^{22}$ Zob. Andrzej Maryniarczyk, Realistyczna interpretacja rzeczywistości (Lublin: Polskie Towarzystwo Tomasza z Akwinu 2005).
} 
związane z brakiem odniesienia do podmiotowej strony moralności (świadomość, przeżycia, uczucia towarzyszące i inne). W tym miejscu należy jednak odnotować, że przedstawiciele neotomizmu lowiańskiego, na przykład Konstanty Michalski, podejmowali już próby tworzenia koncepcji wychowania moralnego uwzględniającej nie tylko dane filozofii przedmiotu, ale także podmiotu. Obecnie ten słuszny postulat realizuje w pełni Szkoła Personalizmu Etycznego, której początek dał Karol Wojtyła ${ }^{23}$.

Interesujące poznawczo są też koncepcje wychowania moralnego tworzone w ramach pedagogiki kultury w okresie II Rzeczypospolitej, autorstwa S. Hessena. B. Suchodolskiego oraz B. Nawroczyńskiego. Są one przykładem, jak się wydaje, udanego połączenia umiarkowanego realizmu z racjonalnym idealizmem, gdzie poznanie zostało dopełnione myśleniem nad rzeczywistością moralności osoby i przebiegiem jej rozwoju 24 .

Wybór tradycji filozoficznej rzutuje także na rozumienie moralności oraz kształt konkretnej etyki. Dlatego dla dopełnienia wcześniejszych refleksji zostanie obecnie ukazana istota sporu o moralność i etykę. Te i wcześniej zaprezentowane analizy pomogą odkryć novum i specyfikę personalizmu etycznego lubelskiej szkoły, która za źródło powstania adekwatnej etyki oraz koncepcji wychowania moralnego uważa (i słusznie) realistyczne, integralne doświadczenie.

\section{Istota sporu o moralność i etykę}

W centrum sporu o moralność i etykę znajduje się problem epistemologicznych podstaw moralnych przekonań oraz źródeł ocen i norm moralnych, a także zagadnienie rozumienia natury dobra moralnego 25 . Spory o racjonalność poznania moralnego dobra i jego naturę toczą się pomiędzy kognitywistami i akognitywistami ${ }^{26}$.

Kognitywiści (łac. cognitio - poznanie) twierdzą, że istnieją obiektywne podstawy ocen i norm moralnych, które można ująć w aktach poznawczych. $Z$ tego

\footnotetext{
${ }^{23}$ Zob. Horowski, Wychowanie, 93-108, 383-384; Tadeusz Biesaga, „Personalizm etyczny K. Wojtyły”, w: Powszechna encyklopedia, t. 4, 721-726.

${ }^{24}$ Zob. Maliszewski, Teoria.

${ }^{25}$ W tym sporze zamiennie używa się pojęć „dobro” i „wartość”, co ma odzwierciedlenie także w tej części artykułu. Jednak dla realistycznej i integralnej etyki nadal podstawowym pojęciem pozostaje „dobro” rozumiane jako wartość absolutna, powiązana z prawdą i pięknem oraz z odpowiedzialnością, na co wskazują analizy doświadczenia etycznego (zob. Wiśniewski, „Wartość, 603-609). Są i tacy myśliciele, którzy w sposób rzeczowy krytykują etykę wartości, wskazując na słabość pojęcia „wartości” jako kategorii filozoficzno-etycznej na rzecz etyki agatycznej (dobra). Ciekawą ewolucję w tym przedmiocie przeszło myślenie ks. Józefa Tischnera - od myślenia według wartości na rzecz myślenia według dobra. Historyczna i systemowa analiza relacji zachodzących pomiędzy nimi pozwala stwierdzić, że aksjologizacja etyki pociąga za sobą niebezpieczeństwo jej skrajnej teoretyzacji, znosząc granice pomiędzy porządkiem poznania, mądrości teoretycznej i praktycznej. Związek etyki z aksjologią nie jest konieczny, choć w pewnych kwestiach przydatny, a nawet pożądany (Krzysztof Stachewicz, „Etyka a aksjologia”, w: Etyka. Filozoficzna etyka życia spelnionego, część II, red. Stanisław Janeczek, Anna Starościc [Lublin: Wydawnictwo KUL 2016], 97.

${ }^{26}$ Por. Kazimierz Krajewski, „Racjonalność etycznego personalizmu”, w: Spór o prawdę, red. Andrzej Maryniarczyk, Katarzyna Stępień, Paweł Gondek (Lublin: Polskie Towarzystwo Tomasza z Akwinu 2011), 339-346.
} 
wynika, że przekonania moralne są racjonalizowane, ponieważ opierają się na obiektywnych i poznawalnych dobrach. Kognitywizm występuje w dwóch odmianach: a) intuicjonizm - wartości (dobra) są poznawalne wprost, bezpośrednio, intuicyjnie; b) dyskursywizm - wartości są poznawalne za pomocą złożonej operacji myślowej: rozumowania (dyskursu) ${ }^{27}$.

Wewnątrz kognitywizmu toczy się także spór pomiędzy naturalizmem a antynaturalizmem. Oba stanowiska uznają, że dobro istnieje obiektywnie i podmiot jest zdolny do poznania prawdy o nim, lecz różnią się co do jego statusu oraz sposobu jego poznania. Naturalizm uznaje, że dobro ma charakter zmysłowy ponieważ, po pierwsze, jest cechą przedmiotu, po drugie, jest cechą empiryczną, czyli naturalną. Dobro jest więc własnością tego samego typu co barwa, ciężar, smak czy kształt i można je poznawać zmysłowo. Fakt moralny to przeżycie o charakterze zmysłowym, są nimi przede wszystkim przeżycia przyjemności, przykrości, pożytku oraz korzyści. Poznawalność (racjonalność) dziedziny moralności polega na jej empiryczności, czyli zdolności ujęcia w kategoriach zmysłowych. Sądy etyczne o wartościach i powinnościach są racjonalne, ponieważ są rezultatem ujęcia empirycznej rzeczywistości. Według naturalistów etyka dąży do opisania i wyjaśnienia faktu naturalnego dążenia do przyjemności (naturalizm sensualistyczny) oraz szczęścia wpisanego w ludzka naturę (naturalizm metafizyczny) bądź korzyści poszczególnych ludzi oraz grup społecznych. Naturalizm redukuje więc fakt moralny do dziedziny dążeń, czego konsekwencją jest „likwidacja” specyfiki faktu moralnego oraz odrzucenie doświadczenia etycznego ${ }^{28}$. Z kolei według antynaturalizmu dobro jest własnością swoistą, cechą sui generis nieredukowalną do cech empirycznych, czyli własnością nie-naturalną, ujmowaną za pomocą pozaempirycznej intuicji.

Wracając do pierwszego sporu pomiędzy kognitywistami a akognitywistami, należy zauważyć, że ci ostatni zaprzeczają racjonalności moralności (ocen i norm moralnych), twierdząc, że ma ona charakter pozapoznawczy. Dobro nie jest przedmiotem poznania, a przeżycie wartości nie jest przeżyciem poznawczym. Wartości, które pojawiają się w ludzkim świecie są rezultatem ekspresji, wyrażania własnej postawy emocjonalnej, narzucania ocen bądź wartościowania ${ }^{29}$. Wewnątrz akognitywizmu wyróżnia się dwa stanowiska: a) emotywizm - zakłada się, że wartość jest wytworem sfery emocjonalno-wolitywnej człowieka, a zdania oceniająconormatywne nie podlegają kwalifikacji prawdy, ponieważ nie mają charakteru

27 Przedstawicielami kognitywizmu są etycy tomistyczni, personaliści, fenomenologowie, kantyści i utylitaryści (zob. tamże, 341).

${ }^{28}$ Zob. Kazimierz Krajewski, Etyka jako filozofia pierwsza. Doświadczenie normatywnej mocy prawdy źródtem i podstawą etyki (Lublin: Wydawnictwo KUL 2006), 145-147.

${ }^{29} \mathrm{U}$ podstaw rozumowania akognitywizmu znajdują się założenia aprioryczne, skreślające pewne fakty z zakresu tego, co dane. Takim założeniem jest a) sensualizm - uznanie, że jedynie wartościowym poznaniem jest poznanie zmysłowe, wykluczające tym samym możliwość doświadczania rzeczywistości innej niż dane wrażeniowe. Cognosco zostaje zamienione na cogito - to, co podmiot poznaje jest nie tyle odpoznane, co pomyślane, skonstruowane; b) decyzjonizm - redukcja czynnika intelektualnego na rzecz niczym nie skrepowanej woli (zob. tamże, 143-145). 
logicznego. Oceny i normy moralne wyrażają jedynie emocje podmiotu wydającego ocenę, przez co mają charakter irracjonalny, emocjonalno-wokatywny ${ }^{30} ;$ b) projekcjonizm - wktórym wartość jest czymś wytworzonym i narzuconym („twórczość aksjologiczna”) ${ }^{31}$.

Spór trwający na gruncie etyki przynagla do poszukiwania adekwatnej teorii moralności (etyki), która byłaby w stanie uchwycić specyfikę i dynamikę moralności oraz przygotować bazę (instrumentarium) dla tworzenia adekwatnych koncepcji wychowania moralnego, uwzględniających hic et nunc współczesnego człowieka zanurzonego wideologii postmodernizmu i neoliberalizmu ${ }^{2}$. Wydaje się, że naprzeciw tym oczekiwaniom wychodzi personalizm etyczny Lubelskiej Szkoły Filozoficznej.

\section{Realne i integralne doświadczenie u podstaw etycznego personalizmu}

Punktem wyjścia filozofii Karola Wojtyły i tworzonej przez niego etyki normatywnej mocy prawdy jest integralne doświadczenie człowieka - zarówno zewnętrzne, jak i wewnętrzne - które nie tylko ujawnia bogatą rzeczywistość osoby wraz z jej czynami i poprzez czyny, ale zarazem stwarza podstawy do wyjaśniania i zrozumienia tego, czego się doświadcza33. „Bogactwo i różnorodność doświadczenia stanowią jak gdyby prowokację dla umysłu, aby rzeczywistość osoby i czynu raz pojętą, starał się jak najwszechstronniej ująć i jak najpełniej wytłumaczyć. To jednakże może się dokonać tylko na drodze coraz głębszego wchodzenia w doświadczenie, w jego zawartość. Dzięki temu osoba i czyn zostają niejako wydobyte z mroku. Coraz pełniej i coraz wszechstronniej się wyłaniają, stając przed poznającym je umysłem"34.

U podstaw takiego doświadczenia człowieka znajduje się doświadczenie etyczne, będące integralną częścią doświadczenia osoby. Wojtyła umiejscawia je

\footnotetext{
${ }^{30} \mathrm{~W}$ literaturze przedmiotu wskazuje się na dwa typy emotywizmu: a) emocjonalizm akognitywistyczny (Ch. Stevenson, A. Ayera) oraz b) emocjonalizm kognitywistyczny, przypisujący uczuciom funkcję poznawczą reprezentowany przez fenomenologów, w szczególności przez M. Schelera (zob. Kazimierz Krajewski, „Emocjonalizm w życiu moralnym”, w: Osoba i uczucia, red. Andrzej Maryniarczyk, Katarzyna Stępień, Paweł Gondek [Lublin: Polskie Towarzystwo Tomasza z Akwinu 2010], 429-435).

${ }^{31}$ Przedstawicielami emotywizmu są etycy anglosascy, natomiast projekcjonizmu - etycy i teologowie moraliści reprezentujący idee tzw. kreatywnego rozumu (zob. Krajewski, „Racjonalność, 342).

${ }^{32}$ Zob. Mariusz Sztaba, “Postmodernism and Neoliberalism as Modern Ideologies Threatening Today's Civic Society: An Educator's Afterthought in Terms of Catholic Church Social Doctrine”, in: Religion long forgotten. The importance of Religion in Education towards Civil Society, ed. Dariusz Stępkowski, Andrzej Murzyn (Cracow: Press “Impuls" 2014), 97-110.

33 Rzeczowego opisu integralnego doświadczenia osoby wanalizach lubelskiej szkoły personalizmu etycznego, dostarczają publikacje Witolda Starnawskiego: Prawda jako zasada wychowania. Podstawy pedagogii personalistycznej wnawiązaniu do myśli Karola Wojtyły - Jana Pawta II (Warszawa: Wydawnictwo UKSW 2008), 31-54; Prawda podstawa wychowania. Wychowawcza rola prawdy wedhug Karola Wojtyły (Warszawa: Wydawnictwo Salezjańskie i UKSW 2005), 14-37.

${ }^{34}$ Karol Wojtyła, Osoba i czyn oraz inne studia antropologiczne, wyd. 3 (Lublin: Towarzystwo Naukowe KUL 2000), 64.
} 
w obszarze współdoświadczania siebie i świata w ich nierozłącznym związku35. Jest to „doświadczenie rozumiejące”, bowiem rozum uczestniczy w bezpośredniości ujęcia przedmiotu oraz „realistyczne”, bo sięga bytowego wymiaru przedmiotu doświadczenia. Doświadczenie etyczne nie jest natomiast „sensualistyczne” (to, co jest przedmiotem tego doświadczenia nie jest ujmowane zmysłowo, choć wywołuje rezonans w zmysłach i uczuciach) oraz nie ma charakteru „apriorycznego" ${ }^{6}$. W związku z powyższymi stwierdzeniami $\mathrm{K}$. Wojtyła pisze, że „[...] doświadczenie moralności zawsze tkwi w doświadczeniu człowieka, a poniekąd nawet jest tym doświadczeniem. Implikacja doświadczeń jest wzajemna i dwustronna. Człowiek przeżywa, a więc i doświadcza siebie samego poprzez moralność, która stanowi szczególną podstawę zrozumienia człowieczeństwa. Z drugiej zaś strony doświadczenia moralności a w ślad za tym i jej zrozumienia - niepodobna oderwać od człowieka i człowieczeństwa. Zachodzi tutaj związek istotowy. Istota moralności oraz człowieczeństwa są związane z sobą nierozłącznie"37.

Doświadczenie etyczne jest syntezą wielu warstw i aspektów. Wyróżnia się w nim dwie fazy: a) metaprzedmiotową (nazywaną „doświadczeniem moralnym”), z którą związane są trzy charakterystyczne momenty: poznanie prawdy, w tym szczególnie prawdy o dobru; przeżycie normatywnej mocy prawdy oraz odkrycie moralnej powinności i sumienia; b) przedmiotową (nazwaną „doświadczeniem moralności”) związaną z doświadczaniem przez osobę własnej godności oraz godności drugiego człowieka, a także ze spełnianiem przez nią czynu moralnie dobrego i poprzez to spełnianiem siebie w czynie moralnie dobrym ${ }^{3}$.

\section{Realne doświadczenie jako akt poznania a zagadnienie prawdy}

Doświadczenie to wgląd, który wyprzedza wszelki pogląd, światopogląd oraz teorie na temat człowieka i świata ${ }^{39}$. Jest to akt poznania, dlatego można stwierdzić, że doświadczenie etyczne jest niejako wpisane w akt poznania lub „nadbudowane” na tym akcie. Wśród rozmaitych czynności poznawczych spełnianych przez osobę

\footnotetext{
${ }^{35}$ Karol Wojtyła w swoich antropologiczno-etycznych analizach zauważa, że „doświadczenie każdej rzeczy, która znajduje się poza człowiekiem, łączy się zawsze z jakimś doświadczeniem samego człowieka. Człowiek nigdy nie doświadcza czegoś poza sobą, nie doświadczając w jakiś sposób siebie w tym doświadczeniu. Kiedy jednak jest mowa o doświadczeniu człowieka, to chodzi nade wszystko o fakt, że człowiek styka się, tzn. nawiązuje kontakt poznawczy z sobą samym" (tamże, 51 ).

${ }^{36}$ Oczywiście są rożne koncepcje doświadczenia etycznego, które jednak w większości charakteryzują się redukcjonizmem elementów konstytutywnych tego doświadczenia (zob. Krajewski, Etyka, 31-43; Jakub Gorczyca, Zarys etyki fundamentalnej [Kraków: Wydawnictwo WAM 2014], 47-70).

${ }^{37}$ Karol Wojtyła, „Problem doświadczenia w etyce”. Roczniki Filozoficzne KUL 2 (1969): 19.

${ }^{38} \mathrm{~W}$ artykule nie dokonuję całościowej analizy i prezentacji doświadczenia etycznego, gdyż można się z nim zapoznać w publikacji: Krajewski, Etyka, 53-67.

${ }^{39}$ Zob. Tadeusz Styczeń, „Normatywna moc prawdy, czyli być sobą to przekraczać siebie (w nawiązaniu do Karola Wojtyły etyki jako antropologii normatywnej)", w: Racjonalność w etyce. Normatywna moc prawdy, red. Kazimierz Krajewski (Lublin: Wydawnictwo KUL 2007), 78-87.
} 
szczególną pozycję zajmują akty poznania sądowego, w których to podmiot poznający dokonuje stwierdzenia zachodzenia bądź niezachodzenia przedmiotowych stanów rzeczy ${ }^{40}$. To jest specyficzny moment dla aktów poznania sądowego, który odróżnia go od innych aktów poznania. Jest to asercja, dotycząca sądów faktycznie wydanych, a nie tylko pomyślanych. Istotą aktów z asercją jest uświadomienie sobie zgodności aktu poznania z przedmiotem, do którego ten akt odnosi się, czyli stwierdzenie, że „jest tak”, bądź „nie jest tak”. To uświadomienie dokonuje się dzięki refleksji in actu exercito, czyli towarzyszącej aktowi poznania ${ }^{41}$.

$\mathrm{Z}$ momentem asercji pojawia się obecna w sądzie kategoria prawdy i prawdziwości, rozumiana jako jego cecha sine qua non. W akcie poznania sądowego przedmiot zostaje ujęty jako zastany, określony i niezależny w swoim istnieniu oraz własnościach od podmiotu poznającego. Prawda aktu poznania znajduje fundament w prawdzie samej rzeczy, która polega na odsłonięciu się i zamanifestowaniu. Pierwotnie zatem pojęcie prawdy odnosi się bezpośrednio do ujawniającego się bytu. Prawda jest transcendentna ${ }^{42}$ zarówno wobec aktu, jak i w stosunku do podmiotu tego aktu, co sprawia, że jest podstawą zarówno obiektywizmu, jak i realizmu aktu poznania43. Podmiot, stwierdzając coś w sądzie, zarazem uznaje to, co stwierdza, angażując się tym samym po stronie poznawanej rzeczywistość jako jej świadek i powiernik. Próba zaprzeczenia prawdzie na tym etapie ujawnia heurystycznie, że ma ona moc normowania podmiotu od początku aktu poznania44. Podmiot „widzi”, że zaprzeczając prawdzie, zaprzeczałby samemu sobie. Już tutaj prawda odsłania się jako wartość samoistna, wsobna, pierwsze dobro człowieka, jego affirmabile i zarazem pierwsza norma oraz podstawowa zasada wychowania45. Uznanie prawdy przez podmiot poznający w asercji sądowej jest więc normotwórcze i jawi się jako pierwszy actus humanus ${ }^{46}$. Osoba, doświadczając w przeżyciu asercji normatywnej mocy prawdy, odkrywa kategoryczny nakaz jej respektowania, czyli powinność

40 Według nauki św. Tomasza, przedmiotem materialnym rozumu (obiectum materiale) jest byt, natomiast przedmiotem formalnym, właściwym (obiectum formale) jest prawda. Rozum jako władza duchowa człowieka pozwala mu pozostawać w możliwie wszechstronnym kontakcie z rzeczywistością. Rozum posiada zdolność ujmowania prawdy i odróżniania jej od błędu, fałszu oraz kłamstwa. Istotna dla poznawczej relacji rozumu do wszelkiego bytu jest prawdziwość.

41 Zob. Kazimierz Krajewski, „Od Karola Wojtyły «normatywnej mocy prawdy» do idei etyki jako antropologii normatywnej i filozofii pierwszej”, w: Racjonalność w etyce. Normatywna moc prawdy, red. Kazimierz Krajewski (Lublin: Wydawnictwo KUL 2007), 170-171.

42 Prawda transcendentalna to ontologiczny odpowiednik prawdy bytu (zob. tegoż, Etyka, 112-113).

${ }^{43}$ Zob. tamże, 57-58.

44 Zagadnienie doświadczenia normatywnej mocy prawdy rozwijała w swojej twórczości ks. Tadeusz Styczeń, który sformułował „werytatywna” koncepcję doświadczenia moralnego, w której centralną kategorią etyczną jest prawda (zob. Tadeusz Styczeń, „Etyka jako antropologia normatywna”, w: Wolność w prawdzie, red. Kazimierz Krajewski (Lublin: TN KUL i Instytut Jana Pawła II KUL 2013), 329; Krajewski, „Personalizm, 236-239).

${ }^{45}$ Zob. Witold Starnawski, Prawdajako zasada.

${ }^{46}$ Czyn to actus humanus a zarazem actus personae i actus voluntaries, gdyż będąc działaniem właściwym człowiekowi jako osobie jest równocześnie źródłem jego poznania (zob. Wojtyła, Osoba i czyn, 73-76, 111-115). 
moralną ${ }^{47}$. W ten sposób pole moralności związane jest nieodłącznie z aktem poznania sądowego.

W akcie poznania sądowego osoba uzyskuje informacje zarówno o przedmiocie poznania, jak i mocą refleksji in actu exercito (świadomości prerefleksyjnej) informacje o samym akcie oraz podmiocie tego aktu. Informacja o obiektywnym stanie rzeczy doświadczona i przeżyta przez podmiot staje się autoinformacją o tym, że jest on sam sobie dany w akcie poznania. Co więc osoba poznaje $\mathrm{w}$ akcie poznania sądowego i jaki to ma związek z moralnością?

\section{Specyfika i wieloaspektowość doświadczenia etycznego}

Analiza realistycznego i integralnego doświadczenia etycznego wskazuje na różne aspekty doświadczenia osoby, które z kolei kształtują odmienne, choć komplementarne i nieraz zachodzące na siebie aspekty etycznego personalizmu. Obecnie zostaną one przywołane ze szczególnym zwróceniem uwagi na te elementy, które jawią się jako istotne w procesie realistycznego wychowania moralnego.

\section{Doświadczenie zewnętrzne jako personalistyczne doświadczeniem powinności afirmacji osobowej godności (aspekt przedmiotowy)}

Osoba jest zarówno podmiotem, jak i przedmiotem doświadczenia. W kontekście doświadczenia zewnętrznego K. Wojtyła sformułował tak zwaną normę personalistyczną, która ujmuje osobę na tle świata, na tle różnicy pomiędzy osobą a rzeczą, gdyż ta pierwsza „różni się od rzeczy strukturą i doskonałością" 48 . Norma ta przybiera dwie formuły: a) negatywną, stwierdzająca, że osoba jest takim dobrem, którego nie wolno używać, czyli sprowadzać do roli środka do celu; b) pozytywną, nawiązującą do chrześcijańskiego przykazania miłości, która stwierdza, że właściwym odniesieniem do każdej osoby jest miłość49. W rozumieniu Wojtyły norma personalistyczna ma dwa sensy: preetyczny - opisowy i etyczny - normatywny. Dla doświadczenia zewnętrznego, które jest doświadczeniem osoby (personalistycznym) ten pierwszy sens jest właściwy. Polega on na tym, że norma personalistyczna wskazuje na samą wartość

\footnotetext{
${ }^{47}$ Nie wolno nie respektować prawdy odkrytej przez siebie. Elementarne doświadczenie „mówi” nam, że podlegamy powinności moralnej, którą zastajemy jako coś, co jest nam dane i zadane. Powinność pojawia się niezależnie od pragnień podmiotu, bowiem istnieje w świadomości ostra cezura pomiędzy przeżyciami „,chcę”, a „powinienem”, a także niezależnie od norm stanowionych przez różnych prawodawców. Powinność moralna jest niezależna od tego, czy dane postępowanie opłaca się osobie ze względu na jej zamiary i cele oraz od istnienia obowiązujących nakazów i zakazów. Jest ona nieodłącznie związana z człowiekiem i dokonywanym przez niego samopoznaniem (zob. Krajewski, Etyka, 7-9, 23, 55-56). Kognitywistyczny naturalizm redukuje kategoryczną powinność moralną do powinności teleologicznej (hipotetycznej), która jawi się wówczas jako powinność środka do celu swobodnie wybranego przez podmiot. Również akogniwistyczny decyzjonizm eliminuje racjonalny charakter powinności, redukując ja do aktu decyzji wywołanej naciskiem na podmiot przez instancję nakazodawczą. Oba te stanowiska popełniają błąd redukcji powinności moralnej ad aliud genus, niwecząc tym samym etykę jako naukę normatywną (zob. tamże, 8-9).

${ }^{48}$ Karol Wojtyła, Miłość i odpowiedzialność (Lublin: TN KUL 2001), 109.

${ }^{49}$ Zob. tamże, 42.
} 
osoby50, na jej wewnętrzną aksjologię, która leży u podstaw porządku moralnego, to znaczy moralnego oceniania i normowania. Sens preetyczny omawianej normy jest zarazem uzasadnieniem dla jej etycznego sensu, czyli przykazania (nakazu, powinności) miłości. Warunkiem osobowego ujęcia drugiego człowieka jest doświadczenie samego siebie jako osoby.

\section{Doświadczenie wewnętrzne (godności własnej osoby) przez doświadczanie normatywnej mocy prawdy i spełnianie czynu moralnie dobrego (aspekt podmiotowy)}

W doświadczeniu wewnętrznym ${ }^{11}$ człowiek jest dany sobie jako suppositum humanum (podmiotowość metafizyczna), lecz także jako ludzkie „ja” (podmiotowość fenomenologiczna - świadomościowa, wyrażająca się poprzez przeżywanie siebie jako podmiotu) ${ }^{52}$. To przeżycie pełni podstawową rolę w procesie konstytuowania osobowej podmiotowości53. Co więc osoba odkrywa w akcie poznania sądowego i jaki to ma związek z moralnością?

Po pierwsze, osoba poznaje prawdę o dobru, w tym - dobru moralnym54. Dobro poznajemy zawsze w perspektywie prawdy, przy czym „dobro prawdy” wyprzedza „prawdę o dobru”. Dobrem jest byt, o ile zostanie stwierdzony. Istota transcendentalnego dobra to affirmabile, czyli „domaganie się” respektowania przez

${ }^{50}$ Wartość osoby (jej godność) wynika zjej statusu ontologiczno-aksjologicznego. Człowiek, poznając realny świat przedmiotów, doświadcza zarazem, że jest kimś innym i absolutnie nieredukowalnym do tego, co jest i może być przez niego poznawane. To, co różni go od świata rzeczy, tym samym go wyróżnia (per opposita cognoscitur - według średniowiecznej maksymy metodologicznej) sprawiając, że człowiek jest w nim „osobno” i jawi się sam sobie jako ktoś, kto ten świat transcenduje, dzięki czemu jest w nim „inaczej” i „wyżej”. Dla K. Wojtyły transcendencja to drugie imię osoby, bowiem ukazuje ona najpełniej najgłębsze warstwy jej struktury. Osoba transcenduje naturę poprzez duchowe akty poznania intelektualnego, miłości i wolności oraz akty religijne, objawiając tym samym swoją duchowość (Wojtyła, Osoba i czyn, 151-228; tegoż, „Transcendencja osoby w czynie a autoteleologia człowieka”, w: tegoż, Osoba i czyn, 477-490).

${ }^{51}$ Choć Karol Wojtyła sformułował normę personalistyczną w perspektywie doświadczenia zewnętrznego, to analizował przede wszystkim osobę-podmiot daną w doświadczeniu wewnętrznym informującym o jej spełnianiu się poprzez czyn i jego moralną wartość oraz poprzez relacje interpersonalne. $Z$ kolei dla uczniów Wojtyły, szczególnie T. Stycznia i A. Szostka, którzy doprecyzowali koncepcję doświadczenia etycznego, u podstaw zewnętrznego i wewnętrznego doświadczenia znajduje się doświadczenie normatywnej mocy prawdy oraz osobowa godność, która stanowi wprost przedmiot moralnego doświadczenia, stając się źródłem kategorycznej, czyli moralnej powinności.

${ }^{52}$ Osoba doświadcza siebie jako suppositum personale (aspekt bytowy) oraz subiectum personale (aspekt świadomościowy), tzn. doświadcza siebie jako podmiot i przeżywa siebie jako podmiot (zob. Wojtyła, Osoba i czyn, 73-76, 111-115).

${ }^{53}$ Przeżycie obok funkcji informacyjnej (osoba przeżywając coś, jednocześnie zdobywa informacje o tym, co przeżywa) pełni także funkcję ontologiczną - konstytuuje subiektywność człowieka. W przeżywaniu osoba sama odsłania się sobie. Integralne doświadczenie, a w jego ramach doświadczenie etyczne, wskazuje na osobę ludzką jako podmiot epistemologiczny - poprzez akt poznania prawdy i podmiot moralny - poprzez odpowiedzialność za siebie w świetle poznanej i uznanej prawdy o dobru (zob. tamże, 375-383).

54 „Prawda o dobru” jest wyrażeniem często używanym w studiach antropologiczno-etycznych Karola Wojtyły. W wyrażeniu tym nie chodzi o obiektywną ,prawdę dobra” jaką zna Bóg, ale o „prawdę o dobru” jaką poznaje osoba, uwzględniając obiektywność swojej podmiotowości i swoich stosunków z innymi osobami, światem i Bogiem (zob. tamże, s. 186-187; także Edward Kaczyński, Prawda - dobro - sumienie.Zzagadnień teologii moralnej [Warszawa: Wydawnictwo Pax 2007], 88-124). 
byt, który podmiot poznaje. K. Wojtyła podkreśla ów związek prawdy i dobra, które się wzajemnie przenikają55. Człowiek dąży do dóbr, ale zawsze kieruje się prawdą o dobru. W życiu moralnym prawda rozumu broni przed zrelatywizowaniem dobra, zwłaszcza dobra moralnego oraz przed sprowadzeniem dobra do uczuć (jak chciał D. Hume), emocji (jak uczył M. Scheler) czy też do czystej formy apriorycznego rozumu praktycznego (jak widział to I. Kant). Prawda o dobru jest zasadą świadomego i wolnego działania osoby. Jest momentem rozszczepienia czynów ludzkich na dobre i złe ${ }^{56}$.

Rozum nie tylko ujmuje dobro wświetle prawdy, ale także stwierdza hierarchię pomiędzy dobrami. W ramach doświadczenia prawdy o dobru, podmiot poznaje jego trzy rodzaje: bonum honestum (inne „ja” - osoby), bonum utile (byty pozaosobowe - zwierzęta, rośliny, byty nieożywione) oraz specyficzne dobro bonum delectabile (piękno) ${ }^{57}$. Tylko osoba jest bonum honestum wychodzącym poza utylitarny charakter pozostałych dóbr.

Jest jeszcze szczególny rodzaj dobra, związanego z osobą a istotnego dla moralności, mianowicie dobro moralne chroniące godność osobową podmiotu. Stanowi ono o właściwym człowiekowi sposobie spełniania się w czynie ${ }^{8}$, a tym samym o jego samostanowieniu59, ponieważ osoba spełnia się tylko przez dobro

\footnotetext{
${ }^{55}$ Rozum może i powinien poznawać w sposób naturalny prawdę o dobru, ponieważ zachodzi wzajemny stosunek pomiędzy nimi. Prawda spełnia w stosunku do dobra podobna rolę, jak w stosunku do bytu. Jeśli więc rozum z natury dąży do poznania prawdy o każdym bycie, to równocześnie dąży do poznania prawdy o dobru. Poznanie przez rozum prawdy o dobru jest poznaniem normatywnym, które przybiera charakter rozkazujący i kulminuje się w sądzie sumienia, w akcie roztropności. Normowanie polega na wprowadzaniu zgodności z rozumem (prawdą) w każdy ludzki czyn; jawi się jako centralna funkcja życia duchowego osoby, skupiająca w sobie akt rozumu i woli, a pośrednio angażująca także życie uczuciowe człowieka (zob. Karol Wojtyła, Wyktady lubelskie [Warszawa: KAI 2008], 193-194, 388-390).

${ }^{56}$ Zob. Kaczyński, Prawda, 104-105.

${ }^{57}$ Piękno odsłania wprost byt jako affirmabile, czyli jako dobro ponadutilitarne, świadcząc o tym, że nie można doświadczenia świata sprowadzać wyłącznie do bonum utile (Krajewski, Etyka, 103-104).

${ }^{58}$ W refleksji filozoficznej K. Wojtyły „spełniać czyn” nie znaczy tylko być jego sprawcą, ale również spełniać siebie w nim, to znaczy urzeczywistniać, doprowadzać do właściwej pełni strukturę samostanowienia, podkreślającą podstawowy fakt, że człowiek jest kimś, a nie czymś. Od strony ontologicznej każdy czyn jest jakimś spełnieniem osoby. Aksjologicznie jednak owo spełnianie się osoby ludzkiej jest spełnianiem się tylko przez dobro. Przez zło moralne człowiek znajduje się w sytuacji poniekąd „nie-spełnienia”. Moralność jawi się bowiem jako wewnętrzna właściwość czynów ludzkich. Jest ona związana z czynem rozumianym jako wewnętrzny i nieprzechodni skutek sprawczości, która może mieć dwojaki charakter - przechodni oraz nieprzechodni. Pierwszy dotyczy kształtowania otaczającej rzeczywistości. Tutaj osoba jest źródłem i przyczyną skutków zewnętrznych istniejących poza nią samą. W drugim przypadku sprawczość wiąże świadome działanie człowieka z własnym podmiotem, stając się samostanowieniem (zob. Wojtyła, Osoba i czyn, 194-197).

59 Wolność osoby, dokonującą się przez wolną wolę, utożsamia się z samostanowieniem jako rzeczywistością doświadczalną, najpełniejszą i zarazem najbardziej podstawową. Samostanowienie jest właściwością osoby ujawniającą strukturę samoposiadania, która z kolei jest warunkiem samopanowania. Aby człowiek mógł o sobie stanowić, musi siebie samego posiadać i sobie samemu panować. Samopanowanie oznacza więc właściwość osoby, dzięki której panuje ona nad własnymi dynamizmami. Samoposiadanie zaś to własność, mocą której osoba decyduje o sobie. Struktury samopanowania i samoposiadania stanowią o człowieku jako osobie, decydując ojego ontologicznej oryginalności oraz stanowiąc podstawę transcendencji, która jest wyrazem duchowości człowieka (zob. tamże, 151-211).
} 
moralne. K. Wojtyła przypomina, że „dobrem (moralnym) jest wszystko to, co prawdziwe, a więc zgodnie z rozumną naturą doskonali byt ludzki, co go aktualizuje. Złem zaś moralnym jest wszystko to, co wywiera skutek przeciwny, co dezaktualizuje byt ludzki w samej jego rozumności, dewaluuje go"6o. Dobro moralne to z jednej strony treść subiektywnie poznawana i przeżywana, z drugiej zaś - obiektywna i przedmiotowa, „osadzająca się” w osobowej podmiotowości człowieka61 .

K. Wojtyła, wskazując, że tylko rozum może poznać prawdę o dobru, ukazuje istnienie obiektywnych zasad życia moralnego i takiegoż działania człowieka. Tym samym przeciwstawia się niebezpiecznej w praktyce koncepcji normotwórczego rozumu jako podstawy normotwórczego sumienia62. Prawda o dobru jawi się jako zasada obiektywna, która pozwala człowiekowi odróżnić dobro od zła. Ujęcie samego dobra w świetle prawdy oraz stosunku woli do prawdy o dobru63 powinno być rozpatrywane nie tylko na poziomie władz duchowych, jakimi są rozum i wola, ale przede wszystkim w kontekście osoby, która działa przez te władze i za ich pomocą. Dlatego zagadnienie prawdy o dobru wiąże się także z kwestią sumienia64,

${ }^{60}$ Wojtyła, Wykłady, 390.

${ }^{61}$ Zob. Krajewski, Etyka, 114-115.

${ }^{62}$ Zob. Wojtyła, Osoba i czyn, 180-184; Andrzej Szostek, Natura, rozum, wolność. Filozoficzna analiza koncepcji twórczego rozumu we wspótczesnej teologii moralnej (Rzym: Fundacja Jana Pawła II 1990).

${ }^{63}$ Dojrzały akt wolnej woli zakłada akt poznania, zatem rozum spełnia dwie podstawowe funkcje: subiektywizującą i obiektywizującą. W pierwszej jako świadomość oraz poznanie towarzyszy woli i uzupełnia ją, pełniąc funkcję odzwierciedlającą świadomość oraz funkcję refleksyjną. Obiektywizująca rola rozumu związana jest $\mathrm{z}$ kierowniczą funkcją poznania $\mathrm{w}$ świadomym działaniu, tj. $\mathrm{w}$ czynie. Ona dostarcza osobie wiedzy i samowiedzy, które kierują samostanowieniem oraz całym dynamizmem woli, również w zakresie jej intencjonalności, czyli chcenia dobra-celu. Dzięki współpracy z rozumem akt woli nie jest już tylko przypadkowym „poruszeniem” w kierunku dobra, czyli wartości przedmiotu, ale racjonalnym, poprzedzonym przedstawieniem danego dobra. Człowiek odkrywa siebie jako świadka i powiernika prawdy, czyli wezwanego przez prawdę do autotranscendencji „ku prawdzie” i „w prawdzie” Odkrywa więc $\mathrm{w}$ sobie moc potwierdzenia bądź zaprzeczenia prawdzie, w tym prawdzie o dobru moralnym. Owa moc to właśnie wolność. W ujęciu K. Wojtyły źródłowe odkrycie wolności dokonuje się zawsze w horyzoncie prawdy poznanej i przeżytej przez podmiot. Zanim osoba użyje swojej wolności, już dana jest jej kategoryczna powinność respektowania poznanej prawdy. Wolna wola odsłaniając swoją strukturę: „mogę - nie muszę - chcę”, zostaje w sposób konieczny odesłana do „powinienem”, która to powinność jest przekładem normatywnej mocy prawdy na samozobowiązanie (zob. Wojtyła, Osoba i czyn, 151-191).

${ }^{64}$ Całe zagadnienie spełniania się osoby przez czyn moralnie dobry i poprzez to stawanie się ens morale związane jest z sumieniem. Ono jest władzą, która ujawnia zależność czynów i ludzkiej wolności od prawdy o dobru. Sumienie określa więc prawdziwe dobro w czynie i kształtuje odpowiednią do tego dobra powinność, będącą doświadczalną postacią zależności wolności od prawdy (zob. tamże, 198-206; Mariusz Sztaba, „Pedagogiczne implikacje analizy faktu sumienia”, w: Być człowiekiem sumienia. Interdyscyplinarny namyst nad fenomenem sumienia, red. Roman Ceglarek, Mariusz Sztaba [Częstochowa: Wydawnictwo Archidiecezjalne Regina Poloniae 2015], 95-138). 
powinnością ${ }^{65}$, normą moralną i odpowiedzialnością ${ }^{66}$ Tylko takie ujęcie prawdy o dobru pozwala ukazać ją jako konstytutywny moment moralności ${ }^{67}$.

Po drugie, osoba poznaje prawdę o swojej obiektywnej, rozumnej naturze ${ }^{68}$ i związanej z nią godności osobowej69, co pozwala między innymi na rozstrzygniecie, jakie czyny służą prawdziwemu dobru człowieka, a jakie nie ${ }^{70}$. Czyn jest moralnie dobry, gdy uznaje dobro, jakim jest osoba; jest moralnie zły, gdy to dobro narusza. Poznanie natury człowieka jest absolutnie koniecznym warunkiem określenia szczegółowej treści aktów afirmacji należnej osobie ${ }^{71}$. Natura jawi się więc jako obiektywny i racjonalny drogowskaz ludzkiego działania; bez jej poznania nie jest możliwe efektywne działanie na rzecz dobra osoby ${ }^{72}$, a wpisane w nią inklinacje wyznaczają obiektywny porządek dóbr (ordo bonorum) stanowiący podstawę prawdziwości norm moralnych (ordo caritatis) 73 .

Tym, co łączy poniekąd doświadczenie zewnętrzne z wewnętrznym, jest czyn odsłaniający osobę, co bardzo wyraźnie wykazał K. Wojtyła w swoim studium Osoba i czyn. Czyn określa podmiotowość osobową według zasady operari sequitur esse (działanie ujawnia podmiot tego działania), ponieważ odsłania rozumność, wolność

${ }^{65}$ Zob. Wojtyła, Osoba i czyn, 206-211.

${ }^{66}$ Zob. tamże, 211-216. Odpowiedzialność jest ważną kategorią w etyce oraz w wychowaniu moralnym. Świadczą o tym chociażby różne koncepcje etyki odpowiedzialności i fundamentalne zainteresowanie ta wartością w XX wieku (zob. Ryszard Moń, „Etyki odpowiedzialności”, w: Etyka. Koncepcje etyki, część I, red. Stanisław Janeczek, Anna Starościc [Lublin: Wydawnictwo KUL 2016], 179-210).

${ }^{67}$ Zob. Kaczyński, Prawda, 99-124; Krajewski, „Personalizm”, 247-249.

$68 \mathrm{~W}$ dobie postmodernizmu, dla której to ideologii wszystko jest tymczasowe ipłynne, prawda o niezmiennej ludzkiej naturze jest kontestowana na różny sposób, co rodzi wiele trudności i kryzysów, np. zagadnienie gender; zob. Spór o naturę ludzka, red. Andrzej Maryniarczyk, Katarzyna Stępień, Arkadiusz Gudaniec (Lublin: Polskie Towarzystwo Tomasza z Akwinu 2014); Oblicza natury ludzkiej. Studia i rozprawy, red. Piotr Duchliński, Grzegorz Hołub (Kraków: Wydawnictwo WAM 2010).

${ }^{69}$ Godność osobowa jest centralną wartością w personalizmie etycznym, a zarazem pojęciem trudnym do zoperacjonalizowania (zob. Mariusz Sztaba, „W poszukiwaniu adekwatnego i integralnego rozumienia godności człowieka. Metodologiczne problemy i pedagogiczne implikacje”. Studia Pedagogiczne. Problemy spoleczne, edukacyjne i artystyczne 22 [2013]: 83-100).

70 „Człowiek nie jest tylko biernym zwierciadłem, które odbija przedmioty, ale zachowuje w stosunku do nich swoistą nadrzędność przez prawdę; jest to wyższość prawdy związana z pewnym dystansem do przedmiotów, która jest wpisana w duchową naturę osoby. O tyle też trafnie stara definicja Boecjusza podkreśla rozumność, czyli umysł jako rys wyróżniający osoby: persona est individua substantia rationalis naturae" (Wojtyła, Osoba i czyn, 202-203).

${ }^{71}$ Natura ludzka dzięki osobowej godności jej nosiciela ma charakter normatywny, tzn. wyznacza słuszność postępowania, pozwalając na uchwycenie specyfiki moralnego dobra, które polega na adekwatnej w stosunku do osoby odpowiedzi respektującej doświadczalnie dany ontologiczno-aksjologiczny status osoby. Takie ujęcie relacji osoby i natury pozwala na unikniecie błędu zarówno naturalizmu, który redukuje osobę do natury, jak i antynaturalizmu, odrywającego osobę od natury (zob. Krajewski, „Racjonalność, 351).

${ }^{72}$ Na potrzebę odczytania natury ludzkiej jako zadanej do afirmacji wskazuje prawo naturalne i związane z nim inklinacje (naturalne skłonności, o których uczyła już klasyczna etyka), odsyłające do pewnych dóbr, bez których respektowania nie ma prawdziwej afirmacji osoby. Zalicza się do nich: a) inklinację do zachowania życia, wskazującą na wartość życia; b) inklinację do przekazywania życia, wskazującą na miłość jako szczególne dobro oraz c) inklinację do integralnego osobowego rozwoju przez rozumną wolność, dokonującą się w prawdzie, dobru i miłości.

${ }^{73}$ Należy w tym kontekście pamiętać o tym, że norma jest zawsze wtórna wobec dobra. 
i sprawczość podmiotu działania. Dla prowadzonych w artykule analiz ważna jest specyfikacja personalistycznej i moralnej wartości czynu. Ta pierwsza wynika z działania, które ma charakter autentycznego samostanowienia osoby: realizuje się w nim jej transcendencja, co pociąga za sobą integrację w polu somatyki, psychiki oraz duchowości74. Personalistyczna wartość czynu jest podstawowym wyrazem wartości samej osoby i wartości, które tkwią w osobie. Wartość moralna czynu polega natomiast na odniesieniu go do prawdy o dobru, do normy moralnej. Na tym też polega autotranscendencja człowieka, który „musi stale [...] niejako przekraczać siebie w kierunku dobra prawdziwego: jest to podstawowy kierunek owej transcendencji, która stanowi właściwość osoby ludzkiej proprium personae"75.

Analiza doświadczenia zewnętrznego i wewnętrznego wyraźnie wskazuje na to, że człowiek osiąga sobie właściwą transcendencję i autoteleologię ${ }^{76}$ poprzez wartość moralną czynu77. „Moralność w sposób podstawowy określa personalistyczny wymiar człowieka"78. Morale jest zakorzenione w personale ${ }^{79}$.

\section{Doświadczenie międzyosobowe jako uczestnictwo i osobowe bycie darem (aspekt komunijny)}

K. Wojtyła podkreśla w autorskiej adekwatnej antropologii ${ }^{80}$, że w strukturze osoby ludzkiej jest immanentnie konstytutywna gotowość do bycia dla kogoś drugiego, będąca cechą uwarunkowaną ontologicznie. Ponieważ osoba ludzka jest bytem przygodnym, potencjalnym i niesamowystarczalnym, dlatego z natury jest bytem otwartym na drugą osobę oraz wspólnotę. Od strony negatywnej potwierdza to

\footnotetext{
${ }^{74}$ Integracja osoby jest komplementarnym aspektem transcendencji. Chodzi w niej o podporządkowanie dynamizmu somatycznego (m.in. popędów) i psychicznego (emotywności i emocjonalności) kontroli rozumu i woli po to, aby te dynamizmy brały czynny udział w samostanowieniu, czyli w urzeczywistnianiu się wolności osoby ludzkiej. Integracja osoby w czynie jawi się więc jako proces całego życia polegający na ciągłym poddawaniu natury (z jej dynamizmami psychosomatycznymi) osobie ludzkiej (z jej dynamizmem samostanowienia i sprawczości oraz duchowości); zob. Wojtyła, Osoba i czyn, 288-295; Mariusz Sztaba, „Pedagogia osoby wobec zagadnienia duchowości”. Forum Pedagogiczne 2 (2015): 41-62.

${ }^{75}$ Wojtyła, Osoba: podmiot, 389.

${ }^{76}$ Autoteleologia człowieka polega na samostanowieniu i spełnianiu siebie w czynie moralnie dobrym, co prowadzi równocześnie do zgodności z samym sobą i z prawdą o dobru; zob. Karol Wojtyła, „Transcendencja osoby w czynie a autoteleologia człowieka”, w: Osoba i czyn, 480-487.

77 „Kryterium podziału i przeciwstawienia sprowadza się do prawdy: osoba jako «ktoś» obdarzony dynamizmem duchowym spełnia się poprzez dobro prawdziwe, nie spełnia się natomiast poprzez nieprawdziwe dobro. Linia podziału, rozszczepienia i przeciwstawienia miedzy dobrem a złem jako wartością i przeciw-wartością moralna sprowadza się do prawdy” (Tegoż, Osoba: podmiot, 198-199).

${ }^{78}$ Tegoż, „Podmiotowość i «to, co nieredukowalne» w człowieku”, w: Osoba i czyn, 441.

${ }^{79}$ Osoba jest bytem moralnym, ponieważ cała jej metafizyczna struktura jest podporządkowana moralnej aksjologii. Można powiedzieć, że metafizyka osoby wypełnia się w moralności; zob. Mariusz Sztaba, „Człowiek jako byt moralny w myśli Karola Wojtyły - Jana Pawła II”, w: Człowiek w refleksji Karola Wojtyty - Jana Pawta II. Wybrane aspekty adekwatnej antropologii, red. Anna Różyło, Mariusz Sztaba (Lublin: Wydawnictwo KUL 2014), 115-137.

${ }^{80}$ Zob. Marian Grabowski, „W stronę antropologii adekwatnej”, w: O antropologii Jana Pawła II, red. tegoż, (Toruń: Wydawnictwo UMK 2004), 15-67.
} 
doświadczenie samotności ${ }^{81}$. Natomiast dynamizm i charakter tego otwarcia uwidacznia się i częściowo wyjaśnia w wewnętrznym rysie osoby nazwanym komunijnością ${ }^{82}$, a wyrażającym się poprzez uczestnictwo, transcendencję oraz aspekt daru.

Uczestnictwo ${ }^{83}$ jest wewnętrzną i dynamiczną właściwością osoby. K. Wojtyła opisuje dwa jego podstawowe znaczenia ${ }^{84}$. Pierwsze związane jest z uczestnictwem $\mathrm{w}$ samym człowieczeństwie drugiej osoby przez pozostawanie z nią w żywej relacji. $\mathrm{Na}$ to uczestnictwo wskazuje słowo „bliźni”. Drugie znaczenie polega na spełnianiu siebie jako osoby we współżyciu i współdziałaniu z innymi na rzecz dobra wspólnego ${ }^{85}$. Uczestnictwo swoją pełnię osiąga $w$ „darowości” osoby, to znaczy w zdolności bycia bezinteresownym darem $\mathrm{z}$ samego siebie dla innych ${ }^{86}$. Zdaniem Wojtyły jest to istotny rys osobowego istnienia i działania człowieka. Tej właściwości nie sposób zrozumieć bez wniknięcia w sam byt i dobro, jakie każda osoba stanowi w swojej istocie. Metafizycznymi warunkami możliwości bycia bezinteresownym darem ${ }^{87}$ przez osobę są struktury samoposiadania i samoopanowania ${ }^{88}$.

Autentyczne uczestnictwo tworzy wspólnotę, która nie jest matematyczną wielością podmiotów, ale wielością i różnorodnością relacji. Poprzez dar z siebie osoby są w stanie stworzyć communio personarum, która jest czymś głębszym niż zwyczajna wspólnota. Jest to taki sposób istnienia i działania osób, że „bytując i działając we wzajemnym do siebie odniesieniu (a więc nie tylko bytując i działając «wspólnie»), przez to działanie i bytowanie wzajemnie siebie jako osoby potwierdzają

81 Zob. Mariusz Sztaba, „Pedagogika integracyjna wobec wieloaspektowego problemu samotności człowieka”. Rozprawy Spoteczne 1 (2013): 52-60.

${ }^{82}$ Zdaniem omawianego autora komunijność ujawnia szczególną prawidłowość bytowania osobowego, które jest bytowaniem „z kimś” i „dla kogoś”. Komunia osób oznacza bytowanie we wzajemnym „dla”, tzn. w relacji wzajemnego daru, która wypełnienia pierwotną samotność człowieka. W osobie ludzkiej kryje się nie tylko zdolność bycia darem, ale również zdolność i zarazem głęboka gotowość afirmacji drugiej osoby. Jest ona niczym innym jak podjęciem daru, które poprzez wzajemność stwarza komunię osób.

${ }^{83}$ Kategoria uczestnictwa ma w nauczaniu K. Wojtyły (ale nie tylko) wartość hermeneutyczną, tzn. wyjaśniającą i rozumiejącą. Dzięki niej latwiej zrozumieć jest komunijność osoby ludzkiej i wspólnotę osób jako communio personarum, wyrażającą się poprzez transcendencję i bycie bezinteresownym darem jednej osoby dla innych (zob. Mariusz Sztaba, „Kategoria uczestnictwa w odniesieniu do rodziny w świetle myśli Karola Wojtyły - bł. Jana Pawła II”. Nauki o edukacji 6 (2011): 39-52.

${ }^{84}$ Zob. Karol Wojtyła, „Uczestnictwo czy alienacja?”, w: Osoba i czyn, 447-461.

${ }^{85}$ Zob. tenże, „Osoba: podmiot”, 402-409; Mariusz Sztaba, „Dobro wspólne jako podstawowa wartość społeczna i zasada życia społecznego. Refleksje pedagoga społecznego”, w: Centralne kategorie wspótczesnej i historycznej pedagogiki, seria „Rzeczywistość edukacyjna”, t. 3, red. Sławomir Sztobryn, Krzysztof Kamiński (Łódź: WN TPF Chowanna 2016, [w druku]).

${ }^{86}$ Zob. Karol Wojtyła, „Osobowa struktura samostanowienia”, w: Osoba i czyn, 430-431; Krajewski, „Personalizm, 250-256.

${ }^{87}$ Bezinteresowność jest podstawową cecha daru, która wskazuje na ponadutylitarny charakter samej osoby; zob. Katarzyna Olbrycht, „Rola bezinteresowności w rodzinie”, w: Obudzić (nie)odkryty potencjat matżeństwa i rodziny, red. Alina Rynio, Katarzyna Braun, ks. Marek Jeziorański, Iwona Szewczak (Lublin: Wydawnictwo Episteme 2015), 39-51.

${ }^{88}$ Tylko ten, kto jest własnością samego siebie, może też siebie samego oddać. I podobnie tylko ten, kto jest panem samego siebie, może uczynić siebie darem dla innych. 
i afirmują"89. Przeciwieństwem tak rozumianego uczestnictwa jest alienacja odbierająca (ograniczająca lub uniemożliwiająca) człowiekowi jako osobie możliwość spełnienia siebie na gruncie bytowania i działania „wspólnie z innymi”90.

\section{Doświadczenie przygodności osoby i jej ostatecznej przyczyny (aspekt teistyczny)}

Nie bez wpływu na moralność jest metafizyczne doświadczenie przez osobę poznającą jej własnej przygodności, czyli niekonieczności istnienia. $\mathrm{Z}$ metafizyczną przygodnością wiąże się także przygodność etyczna polegająca na konieczności ciągłego wyboru i nieusuwalnego znajdowania się w „matni” dobra i zła ${ }^{91}$. Osoba jest skazana na wybór pomiędzy dobrem i złem, gdyż rezygnacja z tego także jest wyborem, a próba wyjścia poza nie jest autoiluzją. W kontekście przygodności metafizycznej bardzo ważne jest dostrzeżenie faktu, że byt, który nie istnieje sam $\mathrm{z}$ siebie, domaga się w imię zasady racji ostatecznej proporcjonalnej przyczyny dla swojego istnienia. W przypadku człowieka jest to Absolut Istnienia i Miłości - Bóg92. Przygodność nie niszczy godności osobowej, lecz odsłania jej ostateczne źródło.

Poznanie metafizyczne pozwala więc odkryć Stwórcę człowieka, o którym pisał św. Ireneusz z Lyonu, że gloria Dei homo vivens (chwałą Boga jest człowiek żyjący). Osoba jawi się jako teofania, to znaczy miejsce objawiania się osobowego Absolutu. W taki sposób Bóg jako ostateczna racja istnienia osoby, jawi się zarazem jako ostateczna racja porządku moralnego. Oznacza to w konsekwencji, że akt moralny, nie tracąc swojej autonomii, okazuje się implicite aktem religijnym ${ }^{93}$. Odnosząc się bezpośrednio (explicite) do człowieka, pośrednio (implicite) odnosimy się do jego Stwórcy. Metafizyka pozwala odkryć ostateczne korzenie godności człowieka i zarazem Autora porządku moralnego, który (to porządek) ze swojej istoty jest otwarty na religię94.

\section{Doświadczenie winy/grzechu (aspekt chrystologiczny)}

Po umysłowym poznaniu prawdy odobru oraz po intencjonalnym akcie chcenia sprzęgniętym z momentami rozstrzygnięcia i wyboru następuje moment przejścia od prawdy o dobru do urzeczywistniania tego dobra w czynie, a poprzez nie aktu spełniania się osoby. Jest to moment właściwy w doświadczeniu moralności, która nie jest realizacją spontanicznych chceń woli, ale koordynacją woli z prawdą rozumu o dobru95. Dlatego

\footnotetext{
${ }^{89}$ Karol Wojtyła, „Rodzina jako «communio personarum»”. Ateneum Kaptańskie 83 (1974): 353.

${ }^{90}$ Zob. Wojtyła, „Osoba: podmiot, 409-414.

${ }^{91}$ Zob. tegoż, Osoba i czyn, 198.

${ }^{92}$ Zob. Krajewski, „Personalizm, 256-257.

${ }^{93}$ Zob. tamże.

${ }^{94}$ Zagadnienie to omawiają różni filozofowie etycy w drugiej części publikacji: Etyka. Koncepcje etyki, część I, red. Stanisław Janeczek, Anna Starościc (Lublin: Wydawnictwo KUL 2016), 265-378.

${ }^{95}$ Zob. Wojtyła, Osoba i czyn, 198. Tylko voluntas recta (prawa wola), tj. wola kierująca się prawdą, jest w stanie prowadzić człowieka ku prawdziwemu dobru.
} 
Wojtyła twierdzi, że wolność to „korzeń” stawania się przez osobę dobrym lub złym moralnie ${ }^{96}$. Człowiek spełnia się przez realizację czynu moralnie dobrego, gdy jest wierny poznanej i uznanej prawdzie o dobru moralnym, natomiast nie spełnia się, gdy sprzeniewierza się poznanej prawdzie, realizując czyn moralnie zły. Nie jest to jednak błąd, ale wina moralna prowadząca do autodestrukcji, samounicestwienia moralnego, tragizmu moralnego97.

Człowiek, odrzucając poznaną przez siebie prawdę w akcie wolnego wyboru, odrzuca samego siebie jako jej świadka i powiernika. Wybór sprzeczny z prawdą jest uderzeniem we własną osobową podmiotowość, która polega na wolności w prawdzie, czyli na autotranscendencji. Gdy osoba aktem wyboru przeczy aktowi poznania, wówczas narusza swoją tożsamość, wprowadzając „nie ja” w swoje ,ja”98. Człowiek, czyniąc zło moralne, staje się złym człowiekiem, czyli takim, jakim nie powinien być. Dramat winy polega na tym, że nie jest on w stanie sam się z niego wyzwolić, wina bowiem nie jest tylko złem moralnym, ale także grzechem z powodu sprzeniewierzenia się Stwórcy, który jest Prawdomówny. Etyka, stając wobec problemu winy, stwierdza, że jest on nierozwiązywalny przez nią i wskazuje na teologię moralną, która uczy, że tylko Bóg może oczyścić $\mathrm{z}$ winy, a to jest co innego niż przebaczenie ${ }^{99}$. Odpowiedzią na dramat winy jest chrześcijańska kerygma, którą niesie Objawienie o Bogu Człowieku - Jezusie Chrystusie, jedynym Odkupicielu człowieka ${ }^{100}$.

\section{Zakończenie}

Zaprezentowane powyżej różnorakie aspekty personalizmu etycznego Lubelskiej Szkoły Filozoficznej wyraźnie pokazują, że tylko realne i integralne doświadczenie etyczne może być autentycznym fundamentem dla adekwatnej etyki i koncepcji/teorii wychowania moralnego. Doświadczenie przedmiotowe odsłania osobę jako istotę najdoskonalszą na tym świecie i wartość wsobną, ponadutylitarną. Doświadczenie podmiotowe objawia osobę jako świadka oraz powiernika prawdy i sprawcę czynu, spełniającego się w czynie moralnie dobrym. Doświadczenie międzypodmiotowe odsłania „darowość” osoby urzeczywistniającej się w bezinteresownym darze z samej siebie, zdolnej do tworzenia communio personarum. Wreszcie doświadczenie przygodności osoby oraz jej ostatecznej przyczyny, a także doświadczenie winy odsyłają do źródła istnienia osoby i moralności oraz jej ostatecznego przeznaczenia. Wspomniane doświadczenia pozwalają

96 Moralność jest doskonałością woli, z którą jest ściśle związana. Istoty obdarzone właściwością poznawczą mogą ujmować prawdę, dociekać jej i do niej dążyć. Istoty obdarzone rozumną wolą mogą i powinny realizować dobro moralne (zob. tamże, 147-148).

${ }^{97}$ Jean Paul Sartre taką sytuację nazwał w swoim dramacie Przy drzwiach zamkniętych (1944) piekłem, nie widząc wyjścia z tej sytuacji. Ale ono jest, tylko poza etyką. Niesie ją w sposób szczególny teologia katolicka ze swoją nauką o Bożej łasce i odpuszczeniu grzechów oraz darowaniu win (zob. Krajewski, „Personalizm, 258).

${ }^{98}$ Ks. Tadeusz Styczeń nazywa tę sytuację „sprawą Owidiusza”, przywołując znane jego powiedzenie: Video meliora proboque deteriora sequor - widzę i pochwalam to, co lepsze, lecz wybieram gorsze (zob. tamże, 257).

${ }^{99}$ Zob. tamże, 257-260.

${ }^{100}$ Zob. tamże; Styczeń, „Normatywna, 92-99. 
uzasadnić istnienie i sens takich wartości, jak prawda, dobro (dobro i zło moralne), odpowiedzialność, wolność (samostanowienie), uczestnictwo, sumienie dla rozwoju autentycznej moralności osoby ${ }^{101}$. Co więcej, wbrew postmodernistycznemu irracjonalizmowi, przywracają one wdziałaniu człowieka (uzasadniając to) należne miejsce rozumowi i jego zdolności do odkrywania prawdy (demaskując tym samym takie stanowiska jak sceptycyzm, agnostycyzm, relatywizm) oraz wolnej woli, zdolnej do wyboru prawdziwego dobra moralnego.

Personalizm etyczny, wskazując na normatywny charakter doświadczenia ludzkiej osoby i moralny wymiar jej bytowania oraz działania - będący warunkiem pełnego zrozumienia człowieka jako osoby - przyznaje rację kognitywistom broniącym zdolności człowieka do poznania prawdy o wartości (dobru) jako obiektywnych i zastanych przez podmiot poznający istnościach: transempirycznych kategoriach, takich jak istnienie, byt, prawda, dobro, piękno. Personalizm etyczny stoi na stanowisku bezpośredniego poznania prawdy o dobru moralnym, na czele z godnością osobową i prawdy o powinności jej respektowania. Zwraca również uwagę na to, że akognitywizm zamienia argumentację na perswazję, przekreślając tym samym możliwość zaistnienia etyki normatywnej. Dlatego w ramach akognitywizmu jest miejsce tylko na metaetykę, badającą językową ekspresję wyrażeń wartościujących oraz na etologię rozumianą jako socjologia moralności, badająca społeczną genezę ocen i ekspresję norm moralnych ${ }^{102}$.

Personalizm etyczny nie zgadza się ze stanowiskiem naturalizmu, który za jedyne wartościowe poznanie uznaje poznanie zmysłowe, przez co samej moralności przypisuje charakter zmysłowy. Uważa jednocześnie, że w procesie poznawania moralności (wartości moralnych) należy kierować się integralnym i rozumiejącym doświadczeniem, co oznacza, że nie można ograniczać go tylko do doświadczenia zmysłowego, polegającego na doznawaniu treści wrażeniowych, jak tego chcą naturaliści i akognitywiści. Wartość moralna jest czymś doświadczanym, empirycznym w szerokim sensie - jest „jakością postaciową"103, a nie tylko jakością zmysłową. Trudno też zgodzić się z tym, że przyjemność czy korzyść, a nawet dążenie do szczęścia stanowiłyby ostateczne kryteria ludzkiego postepowania. Sensualistyczny empiryzm skutkuje w konsekwencji subiektywizmem i relatywizmem. W świetle personalizmu etycznego odpowiedzią na akognitywizm, naturalizm i antynaturalizm jest „realistyczne, rozumiejące i intersubiektywnie kontrolowalne doświadczenie osobowej godności człowieka ujmowanej z jednej strony na tle całego dostępnego nam empirycznie świata, z drugiej zaś także w kontekście treściowego poznania bytu

${ }^{101}$ Wychowanie moralne jest w gruncie rzeczy wychowaniem do egzystencjalnie ważnych wartości i zasad (Marek, „Podstawy, 33-56).

${ }^{102}$ Zob. Krajewski, „Racjonalność, 344.

103 Jest to także uwaga skierowana wstronę antynaturalizmu, który wartość traktuje jako cechę nieempiryczną, odrywając ja od podłoża, od bytu i wyprowadzając tym samym porządek aksjologiczny poza racjonalna sprawdzalność. Wartość w takim razie jest jakością postaciową o „pozacechowej” strukturze (zob. tamże, 345). 
ludzkiego. U źródeł etycznego personalizmu leży zatem prawda o doświadczalnym poznaniu osobowej godności człowieka"104 i normatywna moc prawdy o dobru moralnym.

Personalizm etyczny Szkoły Lubelskiej jest więc kognitywizmem i antynaturalizmem. Jest też nową orientacją filozoficzno-etyczną wyrosłą na gruncie chrześcijańskim ${ }^{105}$. A czym w takim razie nie jest? Na to pytanie można odpowiedzieć, przyglądając się współczesnym kierunkom filozoficzno-etycznym, które w większości charakteryzują się utylitaryzmem, subiektywizmem, relatywizmem, sytuacjonizmem oraz dążnością do eksperymentowania. Zresztą w ponowoczesności etykę normatywną uważa się za zagrożenie dla indywidualnej wolności (Z. Bauman), z tego też powodu nawołuje się do rezygnacji z wielkich teorii etycznych, opierających się na jakichś uniwersalnych i ostatecznych fundamentach (R. Rorty) ${ }^{106}$.

Lubelska szkoła personalizmu etycznego zainicjowana przez Karola Wojtyłę ${ }^{107}$ bardzo wyraźnie wskazuje, że adekwatną etykę i korzystające z niej koncepcje wychowania moralnego trzeba tworzyć w oparciu o realne, integralne doświadczenie etyczne, któremu należy oddać głos i pozwolić wypowiedzieć się do końca. Etyka bowiem to nic innego jak usystematyzowany wyraz zawartości owego doświadczenia oraz pełna jego eksploatacja. Autentyczna etyka nie powinna więc zajmować się kreowaniem sztucznej rzeczywistości moralnej, ale powinna być jej jak najpełniejszym odczytywaniem (realizm).

Lubelska Szkoła Personalizmu Etycznego upomina się o to, aby nie zaczynać od teorii doświadczenia, ale od niego samego, od tego, co jest, tak jak jest i jak się jawi. Dedukcja nigdy nie zastąpi doświadczenia, które podmiotowi poznającemu odsłania rzeczywistość wraz z jej zagadkami, prowokując do stawiania pytań pod jej adresem. Szacunek Lubelskiej Szkoły Personalizmu Etycznego dla doświadczenia zaowocował zespoleniem rozdzielanych dotąd elementów, wypracowanych na gruncie przeciwstawianych sobie nurtów filozoficznych: metafizycznej filozofii człowieka (szerzej - filozofii bytu) i filozofii świadomości w jedną integralną, a przez to adekwatną teorię człowieka. Respekt dla realistycznego, integralnego i zarazem integrującego doświadczenia oraz dla normatywnej mocy prawdy sprawia, że primum ethicum et primum anthropologicum et primum metaphysicum et primum gnoseologicum convertuntur ${ }^{108}$.

${ }^{104}$ Tamże, 344.

${ }^{105}$ Nie ma jednej etyki chrześcijańskiej, choć wiodącą jest etyka tomistyczna, na bazie której Karol Wojtyła tworzył etykę normatywnej mocy prawdy; zob. Tadeusz. Ślipko, Zarys etyki ogólnej (Kraków: Wydawnictwo WAM 2002), 7-13.

${ }^{106}$ Zob. tamże, 14-19, 29-33; Gorczyca, Zarys, 39-43.

${ }^{107}$ Zob. Styczeń, „Kardynał, 381-393.

${ }^{108}$ Krajewski, „Od Karola, 186. 
Adekwatną etykę i koncepcje/teorie wychowania moralnego można więc tworzyć tylko i wyłącznie na bazie realnego oraz integralnego doświadczenia osoby, w ramach którego znajduje się doświadczenie etyczne ${ }^{109}$.

St r e s z c z e n i e: Wychowanie moralne, będąc wewnętrzną formą każdej innej dziedziny wychowania, jest istotne w jego całożyciowym procesie. Istota konkretnej koncepcji wychowania moralnego zależy od tego, w jakiej tradycji filozoficznej była ona kształtowana: w realizmie czy też $\mathrm{w}$ idealizmie. Wychowanie moralne będące pod wpływem idealizmu traci kontakt z rzeczywistym wychowankiem i staje się nieadekwatne, a nawet utopijne (np. wychowanie moralne Rousseau, socjalistyczne, postmodernistyczne itd.). Z kolei wychowanie moralne kształtowane na bazie realizmu dąży do poznania wychowanka i adekwatnego formowania jego morale. W proponowanym artykule zostaje ukazany związek pomiędzy konkretną etyką normatywną budowaną na bazie realistycznego doświadczenia etycznego przez lubelską szkołę etycznego personalizmu a adekwatną koncepcją wychowania moralnego.

Słowa kluczowe: doświadczenie etyczne, personalizm etyczny, poznanie, prawda, dobro moralne, sumienie

\section{Bibliografia}

Adrjanek, Ryszard. Wychowanie moralne w nauczaniu Jana Pawla II. Kraków: Wydawnictwo WSF-P „Ignatianum”, 2003.

Bauman, Zygmunt. Etyka ponowoczesna. Warszawa: Wydawnictwo Altheia, 2011.

Biesaga, Tadeusz. „Personalizm etyczny K. Wojtyły”. W: Powszechna encyklopedia filozofii, t. 4, red. Andrzej Maryniarczyk, Witold Daszkiewicz, Teresa Zawojska, Agata Szymaniak, 721-726. Lublin: Polskie

Towarzystwo Tomasza z Akwinu, 2003.

Bronk, Andrzej. Zrozumieć świat wspótczesny. Lublin: TN KUL, 1998.

Chodna, Imelda. Edukacja amerykańska. Drogi i bezdroża. Lublin: Wydawnictwo KUL, 2008.

Etyka. Koncepcje etyki, część I, red. Stanisław Janeczek, Anna Starościc. Lublin: Wydawnictwo KUL, 2016.

Gara, Jarosław. „Realizm”. W: Encyklopedia pedagogiczna XXI wieku, t. V, red. Tadeusz Pilch, 64-66. Warszawa: WA „Żak”, 2006.

Gielarowski, Andrzej. „Natura, jako to, co upragnione. Analiza koncepcji natury ludzkiej u J.J. Rosseau”. W: Oblicza natury ludzkiej. Studia i rozprawy, red. Piotr Duchliński, Grzegorz Hołub, 53-78. Kraków: Wydawnictwo WAM, 2010.

Gorczyca, Jakub. Zarys etyki fundamentalnej. Kraków: Wydawnictwo WAM, 2014.

109 O specyfice i oryginalności etyki normatywnej mocy prawdy w kontekście problemu kształtowania kultury moralnej młodego pokolenia traktuje artykuł Mariusza Sztaby: „Ważność etyki normatywnej dla kształtowania kultury moralnej młodego pokolenia. Refleksja w świetle nauczania Karola Wojtyły - św. Jana Pawła II i jego uczniów". Forum Pedagogiczne 2 (2016) [w druku]. Witold Starnawski w swojej monografii dostarcza cennych analiz woparciu o myśl personalizmu etycznego szkoły lubelskiej dotyczących doświadczenia wychowania jako źródła pedagogii oraz miejsca i roli prawdy w tym doświadczeniu, ze szczególnym akcentem na tzw. wychowanie prawdziwościowe (Starnawski, „Prawda jako, 105-507). Dla tworzenia adekwatnej koncepcji wychowania moralnego są to fundamentalne treści i inspiracje nie do przecenienia. 
Grabowski, Marian. „W stronę antropologii adekwatnej”. W: O antropologï Jana Pawła II, red. tegoż, 15-67. Torun: WN UMK, 2004.

Horowski, Jarosław. Wychowanie moralne wedhug pedagogiki neotomistycznej. Toruń: WN UMK, 2015.

Jaroszyński, Piotr. Metafizyka czy ontologia? Lublin: Polskie Towarzystwo Tomasza z Akwinu, 2011.

Kaczyński, Edward. Prawda - dobro - sumienie. Z zagadnień teologii moralnej. Warszawa: Wydawnictwo Pax, 2007.

Kiereś, Henryk. „Idealizm”. W: Powszechna encyklopedia filozofii, t. 4, red. Andrzej Maryniarczyk, Witold

Daszkiewicz, Teresa Zawojska, Agata Szymaniak, 721-726. Lublin: Polskie Towarzystwo Tomasza

z Akwinu, 2003.

Kowalczyk, Stanisław. Idee filozoficzne postmodernizmu. Radom: Wydawnictwo Polwen, 2004.

Krajewski, Kazimierz. „Personalizm etyczny w lubelskiej szkole filozoficznej”. W: Etyka. Koncepcje etyki, część I, red. Stanisław Janeczek, Anna Starościc, 229-261. Lublin: Wydawnictwo KUL, 2016.

Krajewski, Kazimierz. „Emocjonalizm w życiu moralnym”. W: Osoba i uczucia, red. Andrzej Maryniarczyk, Katarzyna Stępień, Paweł Gondek, 429-435. Lublin: Polskie Towarzystwo Tomasza z Akwinu, 2010.

Krajewski, Kazimierz. Etyka jako filozofia pierwsza. Doświadczenie normatywnej mocy prawdy źródłem i podstawa etyki. Lublin: Wydawnictwo KUL, 2006.

Krajewski, Kazimierz. „Od Karola Wojtyły «normatywnej mocy prawdy» do idei etyki jako antropologii normatywnej i filozofii pierwszej”. W: Racjonalność wetyce. Normatywna moc prawdy, red. Kazimierz Krajewski, 167-187. Lublin: Wydawnictwo KUL, 2007.

Krajewski, Kazimierz. „Racjonalność etycznego personalizmu”. W: Spór oprawdę, red. Andrzej Maryniarczyk, Katarzyna Stępień, Paweł Gondek, 339-356. Lublin: Polskie Towarzystwo Tomasza z Akwinu, 2011.

Łobocki, Mieczysław. Wychowanie moralne w zarysie. Kraków: Wydawnictwo „Impuls”, 2002.

Maliszewski, Krzysztof. Teoria wychowania moralnego wpedagogice kultury II Rzeczypospolitej. Katowice: Wydawnictwo UŚ, 2004.

Marek, Zbigniew. Podstawy wychowania moralnego. Kraków: WAM, 2005.

Maryniarczyk, Andrzej. Realistyczna interpretacja rzeczywistości. Lublin: Polskie Towarzystwo Tomasza z Akwinu, 2005.

Moń, Ryszard. „Etyki odpowiedzialności”. W: Etyka. Koncepcje etyki, część I, red. Stanisław Janeczek, Anna Starościc, 179-210. Lublin: Wydawnictwo KUL, 2016.

Muszyński, Henryk. Podstawy wychowania społeczno-moralnego. Warszawa: PZWS, 1967.

Nowak, Marian. Teorie i koncepcje wychowania. Warszawa: Wydawnictwo Akademickie i Profesjonalne, 2008.

Olbrycht, Katarzyna. „Rola bezinteresowności w rodzinie”. W: Obudzić (nie)odkryty potencjał małżeństwa i rodziny, red. Alina Rynio, Katarzyna Braun, ks. Marek Jeziorański, Iwona Szewczak, 39-51. Lublin: Wydawnictwo Episteme, 2015.

Ratzinger, Józef. Duch liturgii. Przekład Eliza Pieciul. Poznań: Klub Książki Katolickiej, 2002.

Spór o naturę ludzką, red. Andrzej Maryniarczyk, Katarzyna Stępień, Arkadiusz Gudaniec. Lublin: Polskie Towarzystwo Tomasza z Akwinu, 2014.

Stachewicz, Krzysztof. „Etyka a aksjologia”. W: Etyka. Filozoficzna etyka życia spetnionego, część II, red. Stanisław Janeczek, Anna Starościc, 73-98. Lublin: Wydawnictwo KUL, 2016.

Starnawski, Witold. Prawda jako zasada wychowania. Podstawy pedagogï personalistycznej w nawiązaniu do myśli Karola Wojtyly - Jana Pawła II. Warszawa: Wydawnictwo UKSW, 2008.

Styczeń, Tadeusz. „Etyka jako antropologia normatywna”. W: Wolność w prawdzie, red. Kazimierz Krajewski. Lublin: TN KUL i Instytut Jana Pawła II KUL, 2013.

Styczeń, Tadeusz. „Kardynał Wojtyła - filozof moralista”. W: Etyka. Koncepcje etyki, część I, red. Stanisław Janeczek, Anna Starościc, 381-393. Lublin: Wydawnictwo KUL, 2016. 
Styczeń, Tadeusz. „Normatywna moc prawdy, czyli być sobą to przekraczać siebie (w nawiązaniu do KarolaWojtyły etyki jako antropologii normatywnej)”. W: Racjonalność w etyce. Normatywna moc prawdy, red. Kazimierz Krajewski, 78-87. Lublin: Wydawnictwo KUL, 2007.

Szostek, Andrzej. Natura, rozum, wolność. Filozoficzna analiza koncepcji twórczego rozumu we wspótczesnej teologii moralnej. Rzym: Fundacja Jana Pawła II, 1990.

Sztaba, Mariusz, „Kwestia wolności osoby w myśli Karola Wojtyły - Jana Pawła II. Implikacje pedagogiczne”, w: Wolność a wychowanie. Problemy, dylematy, kontrowersje, seria „Rzeczywistość edukacyjna”, t. 2, red. Sławomir Sztobryn, Krzysztof Kamiński, 149-173. Łódź: WN WSP, 2014.

Sztaba, Mariusz, „W poszukiwaniu adekwatnego i integralnego rozumienia godności człowieka. Metodologiczne problemy i pedagogiczne implikacje”, Studia Pedagogiczne. Problemy spoleczne, edukacyjne i artystyczne, 22 (2013): 83-100.

Sztaba, Mariusz. „Postmodernism and Neoliberalism as Modern Ideologies Threatening Today's Civic Society: An Educator's Afterthought in Terms of Catholic Church Social Doctrine”. In: Religion long forgotten. The importance of Religion in Education towards Civil Society, (ed.), Dariusz Stępkowski, Andrzej Murzyn, 97-110. Cracow: Press “Impuls”, 2014.

Sztaba, Mariusz. „Rzecz o fundamentalnym wyborze pomiędzy realizmem a idealizmem w tworzeniu adekwatnej koncepcji wychowania". Roczniki Pedagogiczne 1 (2015): 27-46.

Sztaba, Mariusz. „Człowiek jako byt moralny w myśli Karola Wojtyły - Jana Pawła II”. W: Człowiek w refleksji Karola Wojtyły - Jana Pawła II. Wybrane aspekty adekwatnej antropologï, red. Anna Różyło, Mariusz Sztaba, 115-137. Lublin: Wydawnictwo KUL, 2014.

Sztaba, Mariusz. „Dobro wspólne jako podstawowa wartość społeczna i zasada życia społecznego. Refleksje pedagoga społecznego". W: Centralne kategorie wspótczesnej ihistorycznej pedagogiki, seria „Rzeczywistość edukacyjna”, t. 3, red. Sławomir Sztobryn, Krzysztof Kamiński. Łódź: WN TPF Chowanna, 2016 [w druku].

Sztaba, Mariusz. „Kategoria uczestnictwa w odniesieniu do rodziny w świetle myśli Karola Wojtyły - bł. Jana Pawła II". Nauki o edukacji 6 (2011): 39-52.

Sztaba, Mariusz. „Pedagogiczne implikacje analizy faktu sumienia”. W: Być czlowiekiem sumienia. Interdyscyplinarny namyst nad fenomenem sumienia, red. Roman Ceglarek, Mariusz Sztaba, 95-138. Częstochowa: Wydawnictwo Archidiecezjalne Regina Poloniae, 2015.

Sztaba, Mariusz. „Pedagogika integracyjna wobec wieloaspektowego problemu samotności człowieka”. Rozprawy Spoleczne 1 (2013): 52-60.

Ślipko, Tadeusz. Zarys etyki ogólnej. Kraków: Wydawnictwo WAM, 2002.

Wiśniewski, Ryszard. „Wartość absolutna a problemy moralnej praxis”. W: Etyka. Fïlozoficzna etyka życia spetnionego, część II, red. Stanisław Janeczek, Anna Starościc, 600-612. Lublin: Wydawnictwo KUL, 2016.

Wojtyła, Karol. Miłość i odpowiedzialność. Lublin: TN KUL, 2001.

Wojtyła, Karol. „Problem doświadczenia w etyce”. Roczniki Filozoficzne KUL 17 (1969): 5-24.

Wojtyła, Karol. Osoba i czyn oraz inne studia antropologiczne, wyd. 3. Lublin: TN KUL 2000.

Wojtyła, Karol. „Rodzina jako «communio personarum»”. Ateneum Kaptańskie 83 (1974): 17-31.

Wojtyła, Karol. Wyktady lubelskie. Warszawa: KAI, 2008. 